\title{
Synchronizing the Greenland ice core and radiocarbon timescales over the Holocene - Bayesian wiggle-matching of cosmogenic radionuclide records
}

\author{
F. Adolphi and R. Muscheler \\ Department of Geology - Quaternary Science, Lund University, Lund, Sweden \\ Correspondence to: F. Adolphi (florian.adolphi@geol.lu.se) \\ Received: 16 June 2015 - Published in Clim. Past Discuss.: 9 July 2015 \\ Revised: 11 December 2015 - Accepted: 21 December 2015 - Published: 15 January 2016
}

\begin{abstract}
Investigations of past climate dynamics rely on accurate and precise chronologies of the employed climate reconstructions. The radiocarbon dating calibration curve (IntCal13) and the Greenland ice core chronology (GICC05) represent two of the most widely used chronological frameworks in paleoclimatology of the past $\sim 50000$ years. However, comparisons of climate records anchored on these chronologies are hampered by the precision and accuracy of both timescales. Here we use common variations in the production rates of ${ }^{14} \mathrm{C}$ and ${ }^{10} \mathrm{Be}$ recorded in tree-rings and ice cores, respectively, to assess the differences between both timescales during the Holocene. Compared to earlier work, we employ a novel statistical approach which leads to strongly reduced and yet, more robust, uncertainty estimates. Furthermore, we demonstrate that the inferred timescale differences are robust independent of (i) the applied ice core ${ }^{10} \mathrm{Be}$ records, (ii) assumptions of the mode of ${ }^{10} \mathrm{Be}$ deposition, as well as (iii) carbon cycle effects on ${ }^{14} \mathrm{C}$, and (iv) in agreement with independent estimates of the timescale differences. Our results imply that the GICC05 counting error is likely underestimated during the most recent 2000 years leading to a dating bias that propagates throughout large parts of the Holocene. Nevertheless, our analysis indicates that the GICC 05 counting error is generally a robust uncertainty measurement but care has to be taken when treating it as a nearly Gaussian error distribution. The proposed IntCal13-GICC05 transfer function facilitates the comparison of ice core and radiocarbon dated paleoclimate records at high chronological precision.
\end{abstract}

\section{Introduction}

Paleoclimatology can provide significant insights into natural climate changes and thus, improve our understanding of the climate system. Besides the reconstruction of past climate itself, a precise chronology of each paleoclimate record is crucial to reliably assess the dynamics of the inferred changes. Furthermore, consistent chronologies across multiple paleoclimate records are required to assess the spatiotemporal evolution of climatic events and thus, to test for potential leads and lags within the climate system and ultimately improve the understanding of the underlying processes of past climate change. Two independent key timescales in paleoclimatology of the past 50000 years are the radiocarbon(IntCal13, Reimer et al., 2013) and the Greenland ice core timescale (GICC05, Andersen et al., 2006; Rasmussen et al., 2006; Seierstad et al., 2014; Svensson et al., 2008; Vinther et al., 2006). To be able to infer leads and lags between paleoclimatic changes anchored on these chronologies at high precision, it is crucial to test the consistency between the timescales and establish climate-independent isochrones and thus reduce the influence of their absolute dating uncertainties (e.g., Lane et al., 2013). One method to compare and synchronize different timescales is the use of cosmogenic radionuclide records, such as ${ }^{10} \mathrm{Be}$ and ${ }^{14} \mathrm{C}$ (Muscheler et al., 2008, 2014a, b; Southon, 2002).

Cosmogenic radionuclides such as ${ }^{10} \mathrm{Be}$ and ${ }^{14} \mathrm{C}$ are produced in the atmosphere through a nuclear cascade mainly triggered by incoming galactic cosmic rays (GCR, Lal and Peters, 1967). The flux of GCR reaching the atmosphere is in turn modulated by the strength of the helio- and geo- magnetic fields resulting in varying production rates of ${ }^{10} \mathrm{Be}$ and 
${ }^{14} \mathrm{C}$ (Masarik and Beer, 1999, 2009; Kovaltsov et al., 2012; Kovaltsov and Usoskin, 2010). Thus, increased (decreased) intensity of the solar- and/or geomagnetic field will result in decreased (increased) cosmogenic radionuclide production rates. Therefore, ${ }^{14} \mathrm{C}$ and ${ }^{10} \mathrm{Be}$ production rates co-vary globally due to external processes, making them a powerful synchronization tool.

After production, ${ }^{14} \mathrm{C}$ oxidizes to ${ }^{14} \mathrm{CO}_{2}$ that enters the global carbon cycle and gets stored in various environmental archives such as tree rings, sediments, and speleothems. ${ }^{10} \mathrm{Be}$ attaches to aerosols which are deposited within 1-2 years (Raisbeck et al., 1981) by wet and dry deposition processes and is stored in sediments including polar ice sheets. These "system effects" (i.e., non-production influences on ${ }^{10} \mathrm{Be}$ and ${ }^{14} \mathrm{C}$ records such as the mixing, transport, and deposition of ${ }^{14} \mathrm{C}$ and ${ }^{10} \mathrm{Be}$ ) can challenge an unequivocal reconstruction of cosmogenic radionuclide production rates from paleoarchives and thus, synchronization efforts based on cosmogenic radionuclides.

Due to the large actively exchanging carbon reservoirs, changes in the atmospheric ${ }^{14} \mathrm{C} /{ }^{12} \mathrm{C}$ ratio are attenuated and delayed compared to the corresponding ${ }^{14} \mathrm{C}$ production rate variations (Oeschger et al., 1975). In comparison, ${ }^{10} \mathrm{Be}$ is a more direct recorder of production rate changes. Thus, when comparing ${ }^{14} \mathrm{C}$ and ${ }^{10} \mathrm{Be}$ records directly, this difference in geochemistry has to be taken into account by using carbon cycle models (Muscheler et al., 2004b). However, to be fully realistic, these corrections would require prior knowledge on the variable state of the carbon cycle, which is often difficult to quantify (Köhler et al., 2006).

${ }^{10} \mathrm{Be}$ records (for example from ice cores) can be affected by non-production related processes as well. Firstly, it depends on the assumed mode of deposition (wet vs. dry) whether the ${ }^{10} \mathrm{Be}$ concentration (all wet deposition) or the ${ }^{10} \mathrm{Be}$ flux (all dry deposition) is the better measure of atmospheric ${ }^{10} \mathrm{Be}$ concentration changes (Alley et al., 1995; Delaygue and Bard, 2010). In reality, both modes of deposition contribute to the accumulation of ${ }^{10} \mathrm{Be}$ on the ice sheet. Today, wet deposition processes dominate over dry deposition which accounts for about one third or less of the deposited ${ }^{10} \mathrm{Be}$ in Greenland (Heikkilä et al., 2011; Elsässer et al., 2015). However, this dry / wet deposition ratio has likely been variable over time (Alley et al., 1995). Secondly, a variety of climatic influences can leave an imprint in ice core ${ }^{10} \mathrm{Be}$ records. Atmospheric circulation changes and air mass precipitation history (i.e., ${ }^{10} \mathrm{Be}$ scavenging by precipitation prior to the arrival of the air mass at the ice core site) may, for example, modulate the transport path and efficiency of ${ }^{10} \mathrm{Be}$ delivery to the ice core site (Heikkilä and Smith, 2013; Pedro et al., 2011b, 2012). Furthermore, changes in the exchange rates between stratospheric (high ${ }^{10} \mathrm{Be}$ concentrations) and the tropospheric (low ${ }^{10} \mathrm{Be}$ concentrations) air masses can affect the tropospheric ${ }^{10} \mathrm{Be}$ budget (Pedro et al., 2011a). Thirdly, contrary to ${ }^{14} \mathrm{C},{ }^{10} \mathrm{Be}$ might not be hemispherically well mixed owing to its short atmospheric resi- dence time. This has led to the proposition of a so-called "polar bias" in ice core ${ }^{10} \mathrm{Be}$ records, stating that if polar ${ }^{10} \mathrm{Be}$ records were dominated by ${ }^{10} \mathrm{Be}$ produced at high latitudes, the anisotropy of the geomagnetic shielding would lead to an enhanced solar- and an attenuated geomagnetic modulation signal in polar ${ }^{10} \mathrm{Be}$ records. There is contradicting evidence from data and modelling studies to whether this is the case (Field et al., 2006; Bard et al., 1997; Pedro et al., 2012; Muscheler and Heikkilä, 2011; Heikkilä et al., 2009; Elsässer et al., 2015).

In summary, to be able to use ${ }^{10} \mathrm{Be}$ and ${ }^{14} \mathrm{C}$ as synchronization tools, "system effects" on each radionuclide have to be assessed and corrected for. If successful, this method has the advantage that it can provide near-continuous estimates of timescale differences as opposed to discrete tie-points obtained from tephrochronology (Abbott and Davies, 2012; Lane et al., 2013) or changes in atmospheric trace gases during Dansgaard-Oeschger events (Blunier et al., 1998; Buizert et al., 2015).

\subsection{Aim of this study}

Recently, Muscheler et al. (2014a) assessed the differences of the radiocarbon and ice core timescales for the past 14000 years by comparing GRIP ${ }^{10}$ Be (Yiou et al., 1997; Muscheler et al., 2004b; Vonmoos et al., 2006) and IntCal13 ${ }^{14} \mathrm{C}$ data (Reimer et al., 2013). Here, we revisit this approach using a different statistical framework (Bronk Ramsey et al., 2001) that is computationally less expensive and provides improved error estimates for the inferred timescale differences as compared to the method used in Muscheler et al. (2014a). Furthermore, we test the robustness of the obtained results with respect to the use of different ice core ${ }^{10} \mathrm{Be}$ records as well as potential "system effects" on the radionuclide records. We focus our analysis on the period where dendrochronologically dated high-quality ${ }^{14} \mathrm{C}$ measurements on tree rings are available. While this is theoretically the case back to 12560 cal BP (calibrated before present, AD 1950, Friedrich et al., 2004), the accuracy of the oldest part of treering chronology has recently been questioned (Hogg et al., 2013) causing a gap in the ${ }^{14} \mathrm{C}$ records underlying IntCal13 around $12000 \mathrm{cal}$ BP (Reimer et al., 2013). Hence, we limit our analysis to the Holocene where dendrochronological and ${ }^{14} \mathrm{C}$-data replication is high and most robust (Reimer et al., 2013; Friedrich et al., 2004).

\section{Methods}

\subsection{Data}

The key data used in this paper are shown in Fig. 1. The GRIP ${ }^{10}$ Be record (Vonmoos et al., 2006; Muscheler et al., 2004b; Yiou et al., 1997) covers almost the entire Holocene with a gap between 9400 and 10800 years BP (Before Present 1950 $\mathrm{AD})$ and no data for sections younger than 300 years BP. 
We use the data as presented in Vonmoos et al. (2006) that includes a 61-point binomial filter (roughly corresponding to a 20 -year low-pass filter or a decadal sampling resolution) minimizing weather-related noise in the ${ }^{10} \mathrm{Be}$ data. The GISP2 ${ }^{10} \mathrm{Be}$ record (Finkel and Nishiizumi, 1997) has a gap between 7980 and 9400 years BP and no data for sections younger than 3270 years BP. We used the GISP2 ${ }^{10} \mathrm{Be}$ record on the GICC05 timescale (Seierstad et al., 2014). Its temporal resolution varies between 20 to 60 years with an average of one sample every 35 years. Hence, no smoothing filter was applied. The GISP $2{ }^{10} \mathrm{Be}$ concentrations have been normalized to the same standard used for the GRIP ${ }^{10}$ Be measurements (NIST SRM 4325, see Yiou et al., 1997; Muscheler et al., 2004b). The resulting GRIP and GISP2 ${ }^{10} \mathrm{Be}$ records differ by on average $0.12 \times 10^{4}$ atoms $^{-1}$ of ice. To avoid inhomogeneities when splicing the records together, we adjusted the GISP2 ${ }^{10} \mathrm{Be}$ data accordingly by adding $0.12 \times 10^{4}$ atoms g $^{-1}$ to the GISP2 ${ }^{10} \mathrm{Be}$ record (see Fig. 1). We note that reconciling the ${ }^{10} \mathrm{Be}$ records through normalization instead of addition does not affect the results shown here. The lower panel in Fig. 1 shows atmospheric $\Delta{ }^{14} \mathrm{C}$ (that is ${ }^{14} \mathrm{C} /{ }^{12} \mathrm{C}$ after correction for fractionation and decay relative to a standard) as reconstructed from dendrochronologically dated tree rings (Friedrich et al., 2004) and presented in IntCal13 in 5-year resolution while the underlying data has typically a resolution of 10 years for most of the Holocene (Reimer et al., 2013).

\subsection{Statistical method}

In the following section we will describe the statistics used for the ${ }^{14} \mathrm{C} /{ }^{10} \mathrm{Be}$ comparison. To be able to compare both radionuclides quantitatively, we converted the ice core ${ }^{10} \mathrm{Be}$ records into $\Delta^{14} \mathrm{C}$ variations using a box-diffusion carbon cycle model (Siegenthaler et al., 1980; Muscheler et al., 2004b). The details of this conversion and its uncertainties are addressed in more detail in Sect. 2.4. In the following we will refer to these modelled $\Delta{ }^{14} \mathrm{C}$ variations as " ${ }^{10} \mathrm{Be}$-based $\Delta{ }^{14} \mathrm{C}$ anomalies".

We employ a statistical approach that is commonly used in the "wiggle-match dating" of ${ }^{14} \mathrm{C}$ records that have an initial relative chronology, i.e. the age differences between neighbouring samples are known, such as tree-rings (Bronk Ramsey et al., 2001). Contrary to classical ${ }^{14} \mathrm{C}$-age calibration we use $\Delta^{14} \mathrm{C}$ anomalies, since ${ }^{10} \mathrm{Be}$ cannot provide information on absolute $\Delta^{14} \mathrm{C}$ (and hence, ${ }^{14} \mathrm{C}$-ages) which depends on ${ }^{14} \mathrm{C}$ production rates and the state of the carbon cycle long before the investigated period. Given the results shown in Sect. 3.1 we employ centennial $(<500$ year FFT high-pass filter) $\Delta{ }^{14} \mathrm{C}$ anomalies of the tree-ring and the ${ }^{10} \mathrm{Be}$-based $\Delta^{14} \mathrm{C}$ records for this comparison as shown in Fig. 3. The mathematical formulation remains, however, unchanged. The calibration record, IntCal13 (Reimer et al., 2013), describes $\Delta^{14} \mathrm{C}$ anomalies for each point in time, $R(t)$, with an associated uncertainty, $\delta R(t)$. This can be com-

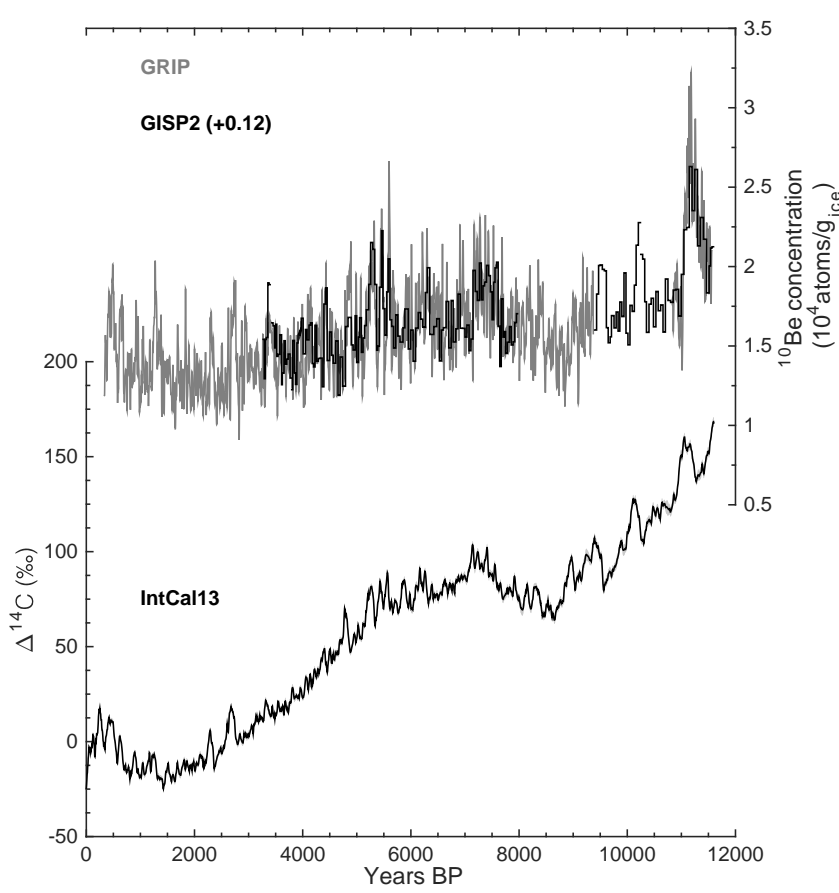

Figure 1. Top: GRIP (grey, Vonmoos et al., 2006) and GISP2 (black, Finkel and Nishiizumi, 1997) Holocene ${ }^{10} \mathrm{Be}$ concentrations. The GRIP ${ }^{10} \mathrm{Be}$ record is smoothed by a $61 \mathrm{pt}$ binomial filter (see Vonmoos et al., 2006). The GISP $2{ }^{10} \mathrm{Be}$ record has been shifted by $+0.12 \times 10^{4}$ atoms $^{-1}$ to correct for a difference in the mean of the GRIP and GISP2 ${ }^{10} \mathrm{Be}$ records. Bottom: atmospheric $\Delta^{14} \mathrm{C}$ as reconstructed from tree rings (Reimer et al., 2013 and references therein).

pared to ${ }^{10} \mathrm{Be}$-based $\Delta^{14} \mathrm{C}$ anomalies $\left(R_{i: n}\right)$ for which we know the absolute age differences $\left(\Delta t_{i}\right)$ between each sample from ice core layer counting. We can estimate the probability $\left(P_{i}\right)$ for different assumed timescale differences between the records $\left(t_{\mathrm{s}}\right)$ for each sample by using Eq. (8) in Bronk Ramsey et al. (2001):

$P_{i}\left(t_{\mathrm{s}}+\Delta t_{i}\right) \propto \frac{\exp \left(-\frac{\left(R_{i}-R\left(t_{\mathrm{s}}+\Delta t_{i}\right)\right)^{2}}{2\left(\delta R_{i}^{2}+\delta R^{2}\left(t_{\mathrm{s}}+\Delta t_{i}\right)\right)}\right)}{\sqrt{\delta R_{i}^{2}+\delta R^{2}\left(t_{\mathrm{s}}+\Delta t_{i}\right)}}$.

Using Bayes' theorem to combine the probabilities for each individual measurement we can obtain an overall probability $\left(P_{\mathrm{s}}\right)$ for each timescale difference between GICC05 and IntCal13 (Eq. 9 in Bronk Ramsey et al., 2001):

$P_{\mathrm{S}}\left(t_{\mathrm{s}}\right) \propto \prod_{i=1}^{n} P_{i}\left(t_{\mathrm{s}}+\Delta t_{i}\right)$

To allow a continuous comparison, all records have been interpolated to annual resolution. However, since the ice core sampling resolution is in reality lower we do not obtain truly independent probability distributions for each sample. Consequently, we correct for the reduced degrees of freedom by 


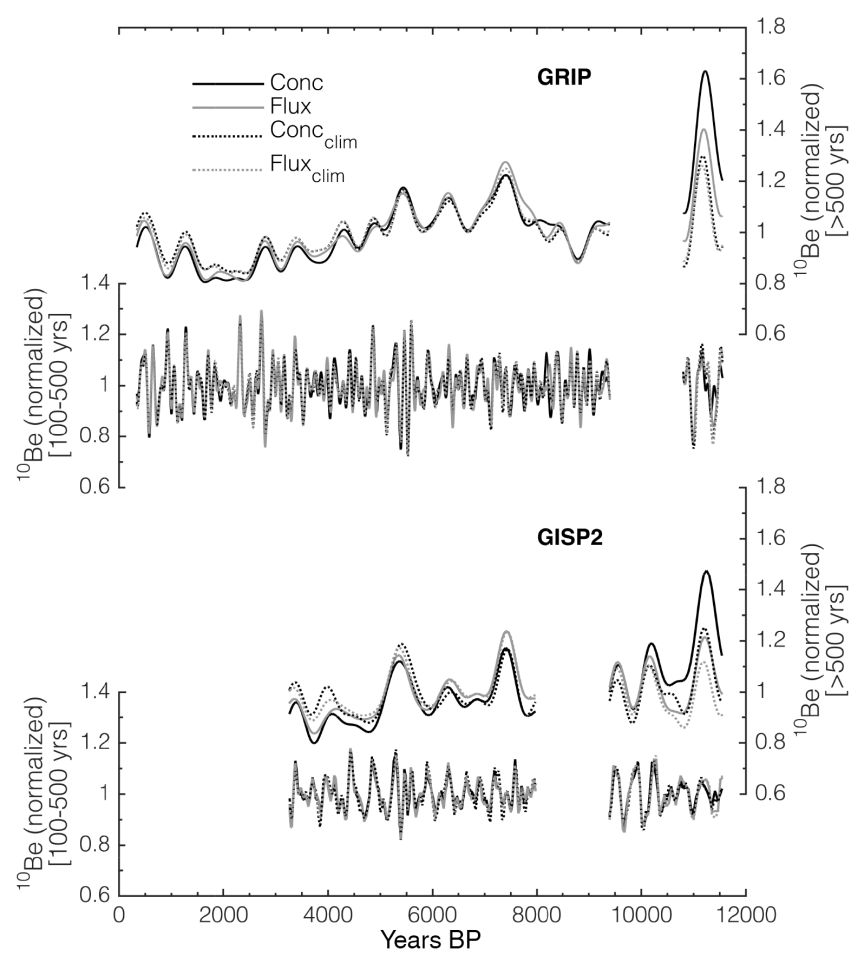

Figure 2. Comparison of ${ }^{10} \mathrm{Be}$ fluxes and concentrations over the Holocene. Solid black and grey curves denote ${ }^{10} \mathrm{Be}$ concentrations and fluxes, respectively. Dotted lines refer to the "climate corrected" (see text) versions of concentrations and fluxes with similar colour coding as solid lines. The top two panels show GRIP ${ }^{10} \mathrm{Be}$ for variations on timescales longer (top) than 500 years, and for wavelengths between 100 and 500 years (below). The 100-year cut-off has been applied for clarity of the figure. The bottom two panels show GISP2 ${ }^{10} \mathrm{Be}$ for the same wavelengths as for GRIP.

scaling $P_{\mathrm{S}}$ as

$P_{\mathrm{s}_{\mathrm{scaled}}}\left(t_{\mathrm{s}}\right)=P_{\mathrm{s}}\left(t_{\mathrm{s}}\right)^{1 / r}$,

where $r$ is the original sample spacing (years sample ${ }^{-1}$ ) of the ice core ${ }^{10} \mathrm{Be}$ records. This scaling effectively widens the obtained probability distribution and thus increases the derived uncertainties. For the filtered GRIP ${ }^{10} \mathrm{Be}$ record, we assume a decadal resolution.

This "wiggle-matching" is done for predefined windows of IntCal13 and GRIP and hence, yields a probability distribution $\left(P_{\mathrm{s}_{\text {scaled }}}\left(t_{\mathrm{s}}\right)\right)$ for their timescale difference for each window. We apply this method to 1000-year windows of ${ }^{14} \mathrm{C} /{ }^{10} \mathrm{Be}$ data and investigate one window every 50 years back in time. For each window we test for timescale differences (shifts) of \pm 150 years without stretching or compression of the timescale within this window. Hence, in analogy to ${ }^{14} \mathrm{C}$-wiggle-match dating, each window could be seen as a single 1000-year long "tree" that is being calibrated. We tested different window sizes between 500- and 2000-year length and the corresponding results are consistent within error. The choice of a 1000-year window represents a trade- off between (i) an increasing statistical robustness and hence, smaller uncertainties, and (ii) a loss of detail (variability) in the final transfer function (see also Sect. 2.5) with increasing window length.

It can be seen from Eq. (1), that contrary to the correlation analysis employed by Muscheler et al. (2014a) this method favours ${ }^{10} \mathrm{Be} /{ }^{14} \mathrm{C}$ linkages with a direct $1: 1$ relationship between IntCal13 and ${ }^{10} \mathrm{Be}$-based $\Delta^{14} \mathrm{C}$ records. Hence, the ${ }^{14} \mathrm{C}:{ }^{10} \mathrm{Be}$ production rate ratio has to be assessed. Furthermore, the uncertainty for the ${ }^{10} \mathrm{Be}$-based records and the ${ }^{10} \mathrm{Be}:{ }^{14} \mathrm{C}$ conversion is quantitatively included in the calculation and hence, needs to be estimated. In the following sections we will outline how these factors can be initially assessed.

\subsection{Assessment of uncertainties due to climatic influences on ${ }^{10} \mathrm{Be}$}

As outlined in the introduction, ice core ${ }^{10} \mathrm{Be}$ records can be affected by various climatic influences that can "contaminate" the production signal. To account for these effects, we use four different versions of the GRIP and GISP2 ${ }^{10} \mathrm{Be}$ records throughout the manuscript. We use ${ }^{10} \mathrm{Be}$ concentrations and fluxes $\left({ }^{10} \mathrm{Be}\right.$ concentration multiplied by snow accumulation and ice density) as endmembers of the assumed mode of ${ }^{10} \mathrm{Be}$ deposition (wet vs. dry, respectively) on the ice sheet. To address the role of climate influences on ${ }^{10} \mathrm{Be}$ mixing and transport to the ice sheet, we additionally generated "climate corrected" versions of the concentrations and fluxes. For this purpose, we performed multiple linear regression analysis between ${ }^{10} \mathrm{Be}$ and climate proxy time series from the GRIP and GISP2 ice cores. Using ice accumulation rates (Seierstad et al., 2014), $\delta^{18} \mathrm{O}$ (Johnsen et al., 1995; Stuiver et al., 1997), and ion data (Mayewski et al., 1997) as predictors, we linearly detrended the ${ }^{10} \mathrm{Be}$ concentrations and fluxes. This procedure removes covariance between ${ }^{10} \mathrm{Be}$ and climate proxy data and may thus, diminish the climate influences in the ${ }^{10} \mathrm{Be}$ record. It should be noted, that this is a "blind" empirical approach that does not aim for a process based understanding of the climate influences on ${ }^{10} \mathrm{Be}$. This method would, for example, confound solar $\left({ }^{10} \mathrm{Be}\right)$ variations that had an influence on climate as climate influences on ${ }^{10} \mathrm{Be}$ (Adolphi et al., 2014). Hence, these "climate corrected" versions should rather be seen as sensitivity tests for our analysis than as improved estimates of past ${ }^{10} \mathrm{Be}$ production rates per se. In summary, we use four (concentrations, fluxes, and "climate corrected" versions thereof) different versions of the GRIP and GISP $2{ }^{10} \mathrm{Be}$ data. Each version represents a plausible endmember of the ${ }^{10} \mathrm{Be}$ production rate history, depending on the assumed mode of deposition and climatic impacts on ${ }^{10} \mathrm{Be}$ and can thus be used to assess the sensitivity of our analysis to these processes. 

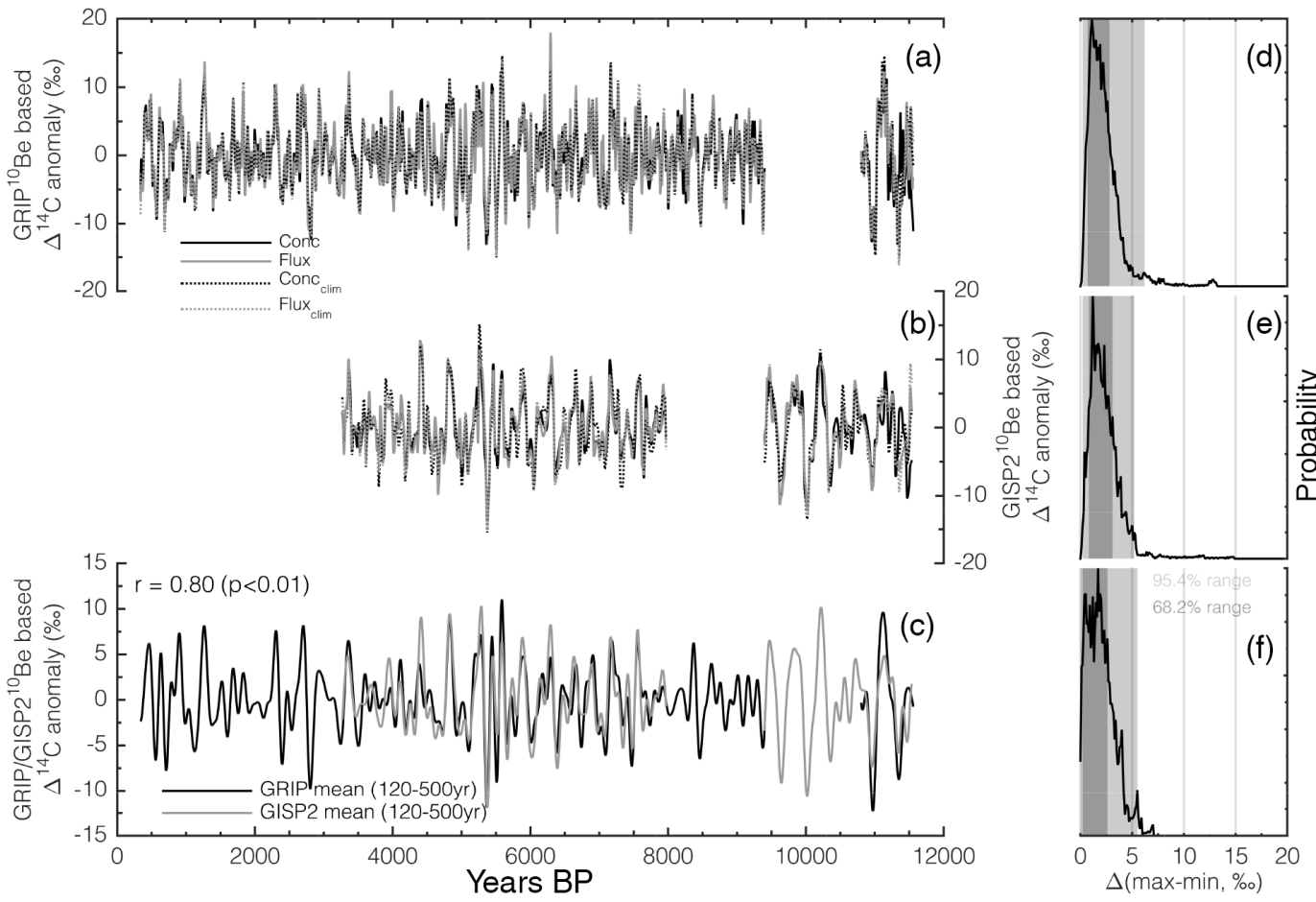

Figure 3. Centennial ( $<500$ years) $\Delta^{14} \mathrm{C}$ variations modelled from GRIP and GISP2 ${ }^{10} \mathrm{Be}$ data. (a) and (b) show the modelled $\Delta^{14} \mathrm{C}$ variations from ${ }^{10} \mathrm{Be}$ concentrations (solid black), fluxes (solid grey), "climate corrected" concentrations (dotted black), and "climate corrected" fluxes (dotted grey) for the GRIP (a) and GISP2 (b) ${ }^{10}$ Be records. (d) and (e) on the right side depict the probability density functions for the maximum $\Delta^{14} \mathrm{C}$ difference between curves shown in (a) and (b), respectively. (c) shows the mean of all GRIP (black) and GISP2 (grey) ${ }^{10} \mathrm{Be}$ based $\Delta^{14} \mathrm{C}$ anomalies shown in (a) and (b), respectively. (f) shows the corresponding probability density function of their maximum $\Delta^{14} \mathrm{C}$ differences. For this comparison both ice core records have been band-pass filtered (120-500 years) to minimize inconsistencies arising from their different sampling resolution. The correlation between the GRIP and GISP2 records is given in (c) together with its $p$ value.

\subsection{Assessment of uncertainties due to ${ }^{10} \mathrm{Be}^{-14} \mathrm{C}$ conversion}

\subsubsection{Carbon cycle modelling}

To be able to compare ${ }^{10} \mathrm{Be}$ to ${ }^{14} \mathrm{C}$ records, we converted the ${ }^{10} \mathrm{Be}$ records into $\Delta{ }^{14} \mathrm{C}$ anomalies using a box-diffusion carbon cycle model (Oeschger et al., 1975; Siegenthaler et al., 1980). The model was run under pre-industrial conditions and has been shown to yield consistent results with more complex carbon cycle models for our purposes (Muscheler et al., 2007). As outlined in the introduction, the unknown state and dynamics of the carbon cycle introduce uncertainty to the comparison of ${ }^{10} \mathrm{Be}$ and ${ }^{14} \mathrm{C}$. To test for the sensitivity to these effects, we conducted four experiments (Table 1). Each experiment was forced with an idealized 200 year ${ }^{14} \mathrm{C}$ production rate cycle of $\pm 20 \%$ approximately corresponding to a solar de Vries cycle. For two of the experiments we perturbed the state of the carbon cycle by increasing (S1) or decreasing (S2) the air-sea gas exchange constant by $50 \%$ mimicking changes in wind speed and/or sea ice extent. In the scenarios S3 and S4 the ocean diffusivity parameter (ocean ventilation) was increased and decreased by $50 \%$, respectively. Each experiment was spun up
Table 1. Performed carbon cycle sensitivity experiments. All percentage values refer to the control simulation under pre-industrial conditions.

\begin{tabular}{lrrrrr}
\hline & Control & S1 & S2 & S3 & S4 \\
\hline Air/Sea exchange & $100 \%$ & $150 \%$ & $50 \%$ & $100 \%$ & $100 \%$ \\
Ocean ventilation & $100 \%$ & $100 \%$ & $100 \%$ & $150 \%$ & $50 \%$ \\
\hline
\end{tabular}

for 50000 years under preindustrial conditions until all ${ }^{14} \mathrm{C}$ reservoirs were in steady state. Subsequently the investigated parameter was changed linearly from its preindustrial to its perturbed value within 50 years (transition 1). The perturbed state was then maintained for 25000 years to reach equilibrium again (steady state) before linearly changing the perturbed parameter back to preindustrial values within 50 years (transition 2). We use these different sensitivity experiments to obtain an uncertainty estimate of the modelled $\left({ }^{10} \mathrm{Be}\right.$ based) $\Delta^{14} \mathrm{C}$ records due to carbon cycle effects. 


\subsection{2 ${ }^{10} \mathrm{Be} /{ }^{14} \mathrm{C}$ production rate ratio}

To compare tree ring and ice core radionuclide records we used the normalized ${ }^{10} \mathrm{Be}$ records as ${ }^{14} \mathrm{C}$ production rate input for the carbon cycle model. This yields a ${ }^{10} \mathrm{Be}$ based $\Delta{ }^{14} \mathrm{C}$ anomaly record that can be directly compared to the tree-ring data. Hence, we have to assume a ratio between the production rates of ${ }^{14} \mathrm{C}$ and ${ }^{10} \mathrm{Be}$. This ratio depends on the radionuclide production cross sections and the energy spectrum of the incoming GCR. Model estimates of relative ${ }^{14} \mathrm{C}:{ }^{10} \mathrm{Be}$ production rate increases for a change in the solar modulation parameter from 700 to $0 \mathrm{MeV}$ at modern geomagnetic field strength differ between 1.34 (Masarik and Beer, 2009) and 1.04 (Kovaltsov et al., 2012; Kovaltsov and Usoskin, 2010). Similarly, the predicted ${ }^{14} \mathrm{C}:{ }^{10} \mathrm{Be}$ production rate ratios for changes in the geomagnetic field strength are model-dependent for unresolved reasons (Cauquoin, 2014).

Furthermore, the ${ }^{14} \mathrm{C}:{ }^{10} \mathrm{Be}$ production rate ratio depends on the presence of a potential "polar bias" (see introduction). If a "polar bias" was present (Bard et al., 1997; Field et al., 2006) the ratio between ${ }^{14} \mathrm{C}$ and ice core ${ }^{10} \mathrm{Be}$ variations could be biased towards lower values. Bard et al. (1997) report a value of 0.65 for the South Pole ${ }^{10} \mathrm{Be}$ record. For Greenland, however, high-resolution ${ }^{10} \mathrm{Be}$ records do not support such a strong polar bias but would instead be consistent with a well-mixed atmosphere (Pedro et al., 2012; Muscheler and Heikkilä, 2011). Simply comparing the standard deviations of centennial variations of IntCal13 and ${ }^{10} \mathrm{Be}$-based $\Delta^{14} \mathrm{C}$ anomalies leads to ratios between 0.95 and $1.05\left(\sigma^{14} \mathrm{C}_{\text {IntCal }} / \sigma^{14} \mathrm{C}_{10} \mathrm{Be}\right)$ depending on which ice core (GRIP/GISP2) and which version of the ${ }^{10} \mathrm{Be}$ records (concentration, flux, climate corrections) is used. Thus, we start with a ${ }^{14} \mathrm{C}:{ }^{10} \mathrm{Be}$ production rate ratio of $1: 1$ and test the sensitivity of our results to this assumption by repeating the calculations outlined in Sect. 2.2 using ${ }^{14} \mathrm{C}:{ }^{10} \mathrm{Be}$ ratios of $1.5: 1$ and $0.5: 1$.

\subsection{Timescale transfer function}

The methodology outlined in Sect. 2.2 yields a probability estimate of the IntCal13-GICC05 timescale difference every 50 years. These probability distributions are, however, not fully independent since neighbouring 1000-year windows overlap and are, hence, largely based on the same data. To create a timescale transfer function we employed a Monte-Carlo procedure that creates 20000 possible transfer functions based on independent, i.e. non-overlapping, windows. Each iteration, (i) randomly selects one of the youngest (most recent) 20 windows and (ii) randomly samples from the probability distribution $P_{\mathrm{s}_{\text {scaled }}}\left(t_{\mathrm{s}}\right)$ of this window as well as the older non-overlapping windows (i.e. one window every 1000 years so that the selected windows are fully independent with respect to the data points they contain). The resulting transfer functions are then interpolated to annual resolution and converted into probability distributions for the timescale difference at each point in time. For each transfer function we assume that both timescales are correct at $0 \mathrm{BP}$ (i.e. AD 1950).

\subsection{Iterative structure of the synchronization method}

The separate aspects of our synchronization method outlined above are applied in an iterative manner to obtain robust and self consistent error estimates for our results. The different steps involved are carried out in the following order.

i. We create four versions of both ice core ${ }^{10} \mathrm{Be}$ records as endmembers of plausible ${ }^{10} \mathrm{Be}$ production rate histories (see Sect. 2.3).

ii. We convert these ${ }^{10} \mathrm{Be}$ records into $\Delta^{14} \mathrm{C}$ using a boxdiffusion carbon cycle model (Sect. 2.4.1) assuming a ${ }^{14} \mathrm{C}:{ }^{10} \mathrm{Be}$ production rate ratio of 1 (see Sect. 2.4.2).

iii. The difference between the different ${ }^{10} \mathrm{Be}$-based $\Delta^{14} \mathrm{C}$ records, and results from the carbon cycle sensitivity experiments (see Sect. 2.4.1) serve as initial uncertainty estimates for the ${ }^{10} \mathrm{Be}$-based $\Delta^{14} \mathrm{C}$ records.

iv. We then compare the tree ring and ${ }^{10} \mathrm{Be}$-based $\Delta^{14} \mathrm{C}$ records with respect to their timescale differences using the statistics outlined in Sect. 2.2. We test for the robustness of these results by using all four different ${ }^{10} \mathrm{Be}$ versions of GRIP and GISP2 separately as well as ${ }^{10} \mathrm{Be}-$ ${ }^{14} \mathrm{C}$ conversion factors of 0.5 and 1.5 (see Sect. 2.4.2).

v. Calculating an initial timescale transfer function (see Sect. 2.5) we then synchronize IntCal13 and GICC05. This enables us to directly compare tree ring and ${ }^{10} \mathrm{Be}$ based $\Delta{ }^{14} \mathrm{C}$ records and estimate the optimal ${ }^{14} \mathrm{C}:{ }^{10} \mathrm{Be}$ production rate ratio, as well as uncertainties for the ${ }^{10}$ Be-based $\Delta{ }^{14} \mathrm{C}$ record.

vi. Based on these posterior estimates of the ${ }^{14} \mathrm{C}:{ }^{10} \mathrm{Be}$ ratio and the uncertainty of the ${ }^{10} \mathrm{Be}$ records, we repeat the calculations outlined in Sects. 2.2 and 2.5 yielding our final estimates of the IntCal13-GICC05 timescale differences over the Holocene.

\section{Results}

\subsection{Climate and carbon cycle related uncertainties in the GRIP and GISP2 ${ }^{10} \mathrm{Be}$ records}

Figure 2 displays the different ${ }^{10} \mathrm{Be}$ production rate scenarios from GRIP (top two panels) and GISP2 (lower two panels) ${ }^{10} \mathrm{Be}$ concentrations (Conc), fluxes (Flux) and their climate corrected versions (Conc $\mathrm{clim}_{\text {clim }}$ and Flux $\mathrm{xlim}_{\text {clim }}$, respectively). Dividing the ${ }^{10} \mathrm{Be}$ records into centennial $(<500$ years) and millennial ( $>500$ years) variations indicates that the different ${ }^{10} \mathrm{Be}$ versions mainly differ in the low-frequency range. 
These millennial differences can systematically affect the modelling of $\Delta^{14} \mathrm{C}$ since the carbon cycle acts as an integrator over ${ }^{14} \mathrm{C}$ production rate variations. The centennial changes in the GRIP ${ }^{10} \mathrm{Be}$ versions, however, are highly coherent and indicate a limited climate influence on ${ }^{10} \mathrm{Be}$ on these timescales and the same holds true for the GISP2 ${ }^{10} \mathrm{Be}$ versions. This is in agreement with Adolphi et al. (2014) who showed that centennial GRIP ${ }^{10} \mathrm{Be}$ variations are dominated by solar activity changes and indicate only little sensitivity to the assumed mode of ${ }^{10} \mathrm{Be}$ deposition even over large deglacial climatic transitions. It should be noted that this statement solely refers to the filtered centennial ${ }^{10} \mathrm{Be}$ variations investigated here. Other potential climatic influences on ${ }^{10} \mathrm{Be}$ such as changes in the stratosphere-troposphere exchange rates are, however, difficult to assess from climate proxy data and will thus not be removed by our detrending technique. Thus, in the following sections we will focus on centennial $\left(<500\right.$ years) changes in ${ }^{10} \mathrm{Be}$ and ${ }^{14} \mathrm{C}$ production rates to avoid systematic errors originating from uncertainties in the millennial ${ }^{10} \mathrm{Be}$ production rate history.

The left-hand panels in Fig. 3 show the corresponding modelled $\Delta{ }^{14} \mathrm{C}$ anomalies from the centennial ${ }^{10} \mathrm{Be}$ variations indicated in Fig. 2 assuming a ${ }^{14} \mathrm{C}:{ }^{10} \mathrm{Be}$ production rate ratio of $1: 1$. As expected, similar to the ${ }^{10} \mathrm{Be}$ records these variations are highly coherent. The right panels in Fig. 3 display histograms of the maximal $\Delta^{14} \mathrm{C}$ difference between the different production rate histories (i.e. the absolute $\Delta^{14} \mathrm{C}$ difference between the highest and the lowest modelled $\Delta^{14} \mathrm{C}$ version at each point in time). It can be seen that the different ${ }^{10} \mathrm{Be}$ versions translate into a modelled $\Delta^{14} \mathrm{C}$ uncertainty of about $\pm 3 \%$ ( $1 \sigma$ ) for GRIP (Fig. 3a, d) and GISP2 (Fig. 3b, e). Similarly, the $\Delta{ }^{14} \mathrm{C}$ anomalies modelled from GRIP and GISP $2{ }^{10} \mathrm{Be}$ agree within $\pm 2.5 \%$ ( $1 \sigma$, Fig. 3c, f).

As outlined in the introduction, the state and the dynamics of the carbon cycle impose an uncertainty on the ${ }^{10} \mathrm{Be}$ ${ }^{14} \mathrm{C}$ comparison that is difficult to quantify from the data itself (Köhler et al., 2006; Muscheler et al., 2004b). Figure 4 shows the results from the performed carbon cycle sensitivity experiments (see Sect. 2.4.1, Table 1). It can be seen that the millennial $\Delta^{14} \mathrm{C}$ variations are substantially altered by carbon cycle perturbations (Fig. 4b). Changes in ocean ventilation (experiments S3 and S4) as well as air-sea gas exchange (experiments $\mathrm{S} 1$ and S2) can cause $\Delta^{14} \mathrm{C}$ anomalies larger than the amplitude of $\Delta^{14} \mathrm{C}$ anomalies induced by ${ }^{14} \mathrm{C}$ production rate changes only (control). However, as before, the centennial $\Delta^{14} \mathrm{C}$ variations are considerably less affected by these perturbations (Fig. 4c). The increase (decrease) of air-sea gas exchange or ocean ventilation does lead to a decrease (increase) in the amplitude of the modelled centennial $\Delta^{14} \mathrm{C}$ variations. However, these changes in amplitude are largely limited to about $\pm 3 \%$ o (Fig. 4 d) except for about 200-300 years around the timing of the carbon cycle perturbation itself (Fig. 4, transitions 1 and 2). Importantly, the phase of the centennial $\Delta{ }^{14} \mathrm{C}$ variations is not affected by

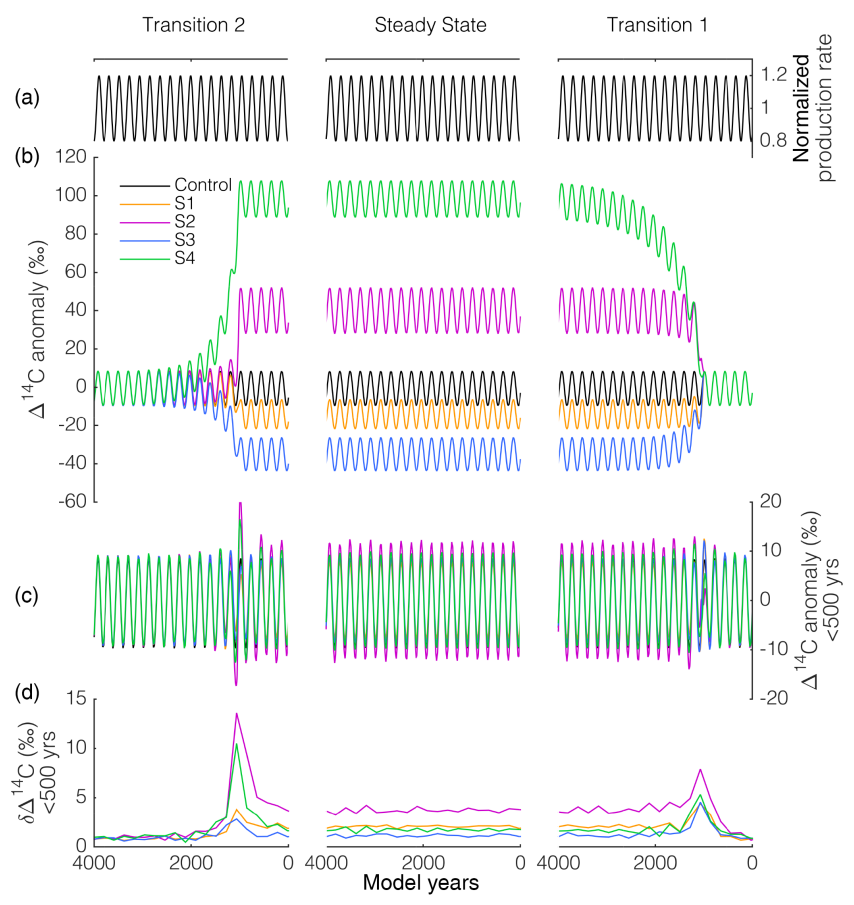

Figure 4. Carbon cycle sensitivity experiments. (a) Normalized ${ }^{14} \mathrm{C}$ production rate input to the model. (b) Modelled $\Delta^{14} \mathrm{C}$ anomaly. (c) centennial ( $<500$ year) anomalies of modelled $\Delta^{14} \mathrm{C}$ shown in (b). (d) differences in the centennial $\Delta^{14} \mathrm{C}$ variations (c) from the control run. All model runs and panels are shown for the transition from preindustrial to perturbed conditions (transition 1 , right), steady state of the perturbed conditions (steady state, middle), and the transition back to preindustrial carbon cycle conditions (transition 2, left). See also Sect. 2.4.1.

the imposed carbon cycle changes. Since the applied carbon cycle changes in our sensitivity experiments are likely unrealistically large for Holocene conditions (Köhler et al., 2006; Roth and Joos, 2013), we conservatively assume a $1 \sigma$ uncertainty of $\pm 3 \%$ o (see Fig. 4 d, "steady state") for the modelled $\Delta^{14} \mathrm{C}$ records due to carbon cycle effects.

Adding the uncertainties due to climate impacts on ${ }^{10} \mathrm{Be}$ $( \pm 3 \%$ ) and the carbon cycle $( \pm 3 \%$ ) in quadrature we thus obtain an initial uncertainty estimate of about $\pm 4.5 \%$ o for the modelled $\Delta^{14} \mathrm{C}$ records.

\subsection{Sensitivity of the synchronization method to uncertainties in the ${ }^{10} \mathrm{Be}-{ }^{14} \mathrm{C}$ conversion}

In the following we will compare the centennial $\Delta^{14} \mathrm{C}$ (i.e., < 500 years, separated by an FFT-based high-pass filter) anomalies reconstructed from tree rings (IntCal13) and ice cores (GRIP/GISP2 ${ }^{10} \mathrm{Be}$-based) with respect to their timescale differences. The choice of a 500-year high-pass filter results from the climate and carbon cycle related uncertainties shown in Sect. 3.1 which increase on longer timescales. We use the statistical framework outlined in 
Sect. 2.2 and assign an initial uncertainty of $\pm 4.5 \%$ o to the ${ }^{10} \mathrm{Be}$-based $\Delta^{14} \mathrm{C}$ records. The uncertainties for the tree-ring based $\Delta^{14} \mathrm{C}$ anomalies are taken from IntCal13 (Reimer et al., 2013). For this purpose we spliced the GISP $2{ }^{10} \mathrm{Be}$ versions into the corresponding GRIP ${ }^{10} \mathrm{Be}$ versions to fill the gap in the GRIP record between 9400 and 10800 years BP and create a continuous record for the entire Holocene. Hence, in the following "GRIP" refers to this combination of GRIP and GISP2 data, while results for the GISP2 data are only shown for periods where they have not been used to fill the gap in the GRIP record.

Figure 5 displays the obtained probability distributions $P_{\mathrm{S}_{\text {scaled }}}\left(t_{\mathrm{s}}\right)$ for each sliding window, centred on its mean age. The results are shown for all four GRIP ${ }^{10} \mathrm{Be}$ versions (panel a), in comparison to results based on GISP2 data only (panel b), as well as for different assumed ${ }^{14} \mathrm{C}:{ }^{10} \mathrm{Be}$ production rate ratios (panel c). The different GRIP ${ }^{10} \mathrm{Be}$ versions yield consistent estimates of the IntCal13-GICC05 timescale differences throughout the Holocene. The only marked difference occurs around the $8.2 \mathrm{kaBP}$ event (Blockley et al., 2012). During this period the ${ }^{10} \mathrm{Be}$ flux indicates a more rapid increase in the IntCal13-GICC05 timescale difference as compared to all other ${ }^{10} \mathrm{Be}$ versions. As noted by Muscheler et al. (2004a) the accumulation rate anomaly associated to the climate oscillation around 8200 years ago appears to lead to an "over correction" of the ${ }^{10} \mathrm{Be}$ deposition during flux calculation. This leads to a worse agreement between ${ }^{14} \mathrm{C}$ and ${ }^{10} \mathrm{Be}$ fluxes as compared to ${ }^{14} \mathrm{C}$ and ${ }^{10} \mathrm{Be}$ concentrations (see Fig. 3 in Muscheler et al., 2004a). This is corroborated by the fact that results based on the "climate corrected" ${ }^{10} \mathrm{Be}$ flux follow the probability estimates of ${ }^{10} \mathrm{Be}$ concentrations (Fig. 5a).

Comparing GRIP based results to GISP2 based estimates indicates consistent estimates of the timescale differences. The larger uncertainties of the GISP2 based results are due to the lower sampling resolution of the GISP2 ${ }^{10} \mathrm{Be}$ record (see Eq. 3).

Figure $5 \mathrm{c}$ shows the sensitivity of our results to the assumed ${ }^{14} \mathrm{C}:{ }^{10} \mathrm{Be}$ production rate ratio. It can be seen that the inferred timescale differences are relatively insensitive to the assumed ${ }^{14} \mathrm{C}:{ }^{10} \mathrm{Be}$ ratio. However, the derived uncertainty of $P_{\mathrm{S}_{\mathrm{scale}}}\left(t_{\mathrm{s}}\right)$ does increase with lower ${ }^{14} \mathrm{C}:{ }^{10} \mathrm{Be}$ ratios. This can easily be understood by imagining a scaling of zero for the ${ }^{10} \mathrm{Be}$-based record which would result in an infinitely wide probability distribution.

In summary, our method of estimating the IntCal13GICC05 timescale difference is (i) largely robust for all versions of the GRIP ${ }^{10} \mathrm{Be}$ record, (ii) consistent for GRIP and GISP2 ${ }^{10} \mathrm{Be}$ data, and (iii) independent of the assumed ${ }^{14} \mathrm{C}:{ }^{10} \mathrm{Be}$ production rate ratio. However, this analysis also shows that it is important to compare ${ }^{10} \mathrm{Be}$ concentrations and fluxes to identify potential caveats as seen around the $8.2 \mathrm{ka} \mathrm{BP}$ event. Furthermore, while the estimate of the most likely timescale difference (i.e. the location of the maximum of $P_{\mathrm{s}_{\text {scaled }}}\left(t_{\mathrm{s}}\right)$ ) may not be affected by the assumed ${ }^{14} \mathrm{C}:{ }^{10} \mathrm{Be}$ (a)

(b)

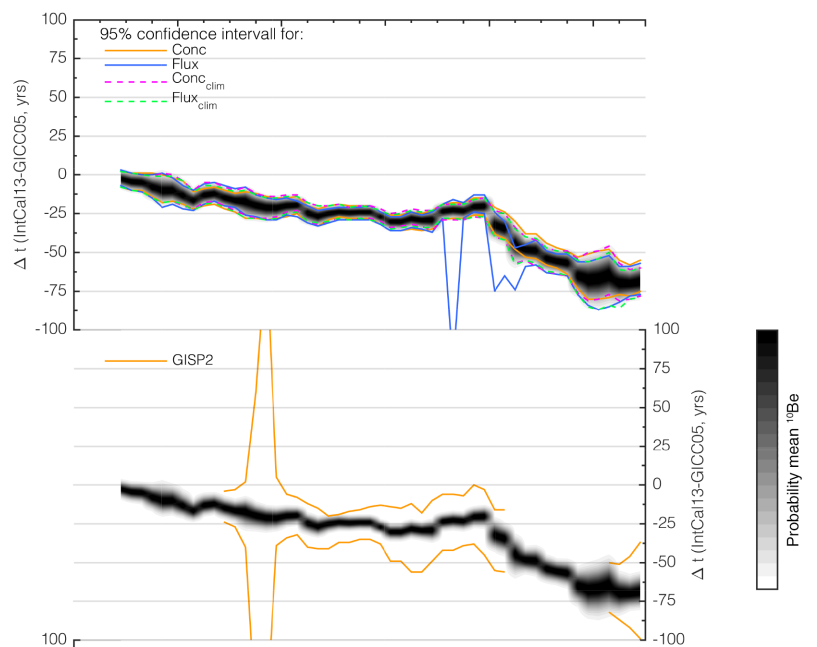

(b)

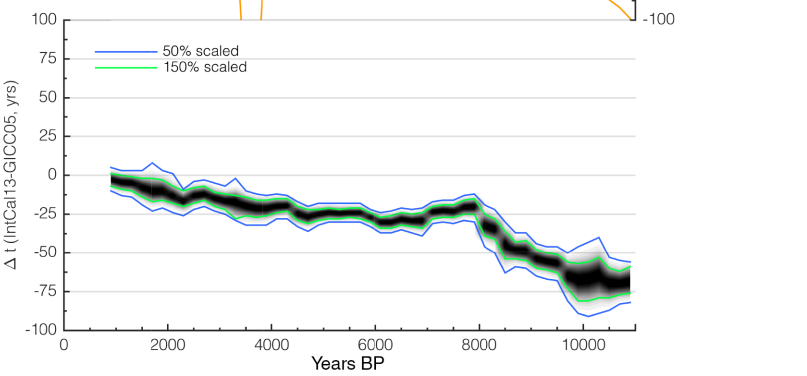

Figure 5. Probability distributions for IntCal13-GICC05 timescale differences $\left(P_{\mathrm{S}_{\text {scaled }}}\left(t_{\mathrm{S}}\right)\right.$, see Sect. 2.1) for each 1000-year window based on the mean of GRIP ${ }^{10} \mathrm{Be}$ concentrations, fluxes, and their climate corrected versions (grey-scale patches in all panels). The gap in the GRIP ${ }^{10} \mathrm{Be}$ record between 9400 and $10800 \mathrm{BP}$ has been filled with data from the GISP2 ice core. Each probability distribution is centred on the mean age of the investigated window. (a) Comparison to $95 \%$ probability intervals based on GRIP ${ }^{10} \mathrm{Be}$ concentrations (solid orange), fluxes (solid blue) and their "climate corrected versions (dashed pink and green lines). (b) Comparison to $95 \%$ confidence intervals based on the mean of GISP $2{ }^{10} \mathrm{Be}$ concentrations, fluxes, and their climate corrected versions. Results for GISP2 are only shown for periods where it has not been used to fill the gap in the GRIP record. (c) Comparison to results based on a different scaling (factors of 0.5 and 1.5 shown as blue and green lines, respectively) of the GRIP ${ }^{10} \mathrm{Be}$ record.

ratio, the uncertainty of this estimate is. Hence, in the following section we will derive a posterior estimate of the ${ }^{14} \mathrm{C}:{ }^{10} \mathrm{Be}$ ratio, as well as a refined uncertainty estimate of the ${ }^{10} \mathrm{Be}$-based $\Delta{ }^{14} \mathrm{C}$ records.

\subsection{Posterior estimate of the ${ }^{14} \mathrm{C}:{ }^{10} \mathrm{Be}$ production rate ratios and uncertainties}

As shown in the previous section, our estimates of the most likely timescale difference between IntCal13 and GICC05 are largely independent of which ${ }^{10} \mathrm{Be}$ record (GRIP/GISP2) and which version thereof (concentration, flux, climate corrections) is used, as well as which ${ }^{14} \mathrm{C}:{ }^{10} \mathrm{Be}$ ratio is assumed. 
Hence, we calculated an initial GICC05-IntCal13 transfer function (Sect. 2.5) and synchronized the tree ring based and ${ }^{10} \mathrm{Be}$-based $\Delta{ }^{14} \mathrm{C}$ record. This enables us to compare the records with respect to the most likely ${ }^{14} \mathrm{C}:{ }^{10} \mathrm{Be}$ ratio. In addition, we can derive a posterior estimate of the modelled ${ }^{10} \mathrm{Be}$-based $\Delta{ }^{14} \mathrm{C}$ uncertainty.

After synchronization we can compare tree ring and ${ }^{10} \mathrm{Be}$ based $\Delta^{14} \mathrm{C}$ sample pairs assuming different ${ }^{10} \mathrm{Be}$ scaling factors (i.e. ${ }^{14} \mathrm{C}:{ }^{10} \mathrm{Be}$ ratios) between zero and two. The difference between tree ring and ${ }^{10} \mathrm{Be}$-based $\Delta^{14} \mathrm{C}$ sample pairs $(\delta(t))$ is a function of the uncertainty of $\operatorname{IntCal13}\left(\delta_{\mathrm{IC}}(t)\right)$ and the uncertainty of the ${ }^{10} \mathrm{Be}$-based records $\left(\delta_{\mathrm{Be}}(t)\right)$ in the form that

$\delta(t)=\sqrt{\delta(t)_{\mathrm{IC}^{2}}^{2}+\delta(t)_{\mathrm{Be}}{ }^{2}}$.

Hence, we can rearrange Eq. (4) and use the quoted uncertainties of IntCal13 to derive $\delta(t)_{\mathrm{Be}}$ :

$$
\begin{aligned}
& \partial(t)_{\mathrm{Be}}=\sqrt{\partial(t)^{2}-\partial(t)_{\mathrm{IC}}{ }^{2}} ; \quad \partial(t)>\partial(t)_{\mathrm{IC}} \\
& \partial(t)_{\mathrm{Be}}=0 ; \quad \partial(t) \leq \partial(t)_{\mathrm{IC}} .
\end{aligned}
$$

These uncertainties can be summarized to the rooted mean square error $\left(\mathrm{RMSE}_{10} \mathrm{Be}\right)$. This way we can obtain the optimal ${ }^{10} \mathrm{Be}$ scaling factor (where the RMSE ${ }_{10} \mathrm{Be}$ minimizes) and the associated uncertainty of the ${ }^{10} \mathrm{Be}$-based $\Delta{ }^{14} \mathrm{C}$ records (the minimum of the RMSE ${ }_{10}{ }_{\mathrm{Be}}$ ). Figure 6 displays the results of this analysis indicating an optimal ${ }^{10} \mathrm{Be}$ scaling factor of around 0.7. Assuming that the centennial ${ }^{10} \mathrm{Be}$ and ${ }^{14} \mathrm{C}$ production rate changes are mainly modulated through solar activity this low scaling factor would point to a strong polar bias of the GRIP and GISP $2{ }^{10} \mathrm{Be}$ records (see Sects. 1 and 2.4.2). However, when investigating the $\Delta^{14} \mathrm{C}$ time series it becomes apparent that this low scaling leads to an underestimation of the amplitude of virtually all grand solar maxima and minima (i.e. large $\Delta^{14} \mathrm{C}$ anomalies) in the ${ }^{10} \mathrm{Be}$-based $\Delta^{14} \mathrm{C}$ record (Fig. 7, top). This bias is induced by the fact that the $\Delta^{14} \mathrm{C}$ anomalies are normally distributed around $0 \%$ leading to a majority of the $\Delta^{14} \mathrm{C}$ values lying close to zero dominating the RMSE ${ }_{10 \mathrm{Be}}$. Hence, for these values a low scaling of the ${ }^{10} \mathrm{Be}$-based $\Delta{ }^{14} \mathrm{C}$ records will simply act to reduce noise from the record and thus reduce the RMSE ${ }_{10} \mathrm{Be}$.

To avoid this bias, we performed a binned regression analysis. We divided the tree ring and ${ }^{10} \mathrm{Be}$-based $\Delta^{14} \mathrm{C}$ sample pairs into bins of $2.5 \%$ (defined based on the tree ring $\Delta^{14} \mathrm{C}$ anomalies) and calculated the RMSE ${ }_{10} \mathrm{Be}$ for each bin $\left(\mathrm{RMSE}_{10} \mathrm{Be} \_\right.$bin $)$. These uncertainties for each bin can then be summarized to an overall $\mathrm{RMSE}_{10} \mathrm{Be}$ as

$\operatorname{RMSE}_{10}{ }_{\mathrm{Be}}=\sqrt{\overline{\mathrm{RMSE}_{10}^{2}{ }_{\mathrm{Be} \_ \text {bin }}}}$.

This binning leads to an equal weighting of small and large $\Delta^{14} \mathrm{C}$ anomalies in the comparison of the $\Delta^{14} \mathrm{C}$ records. It

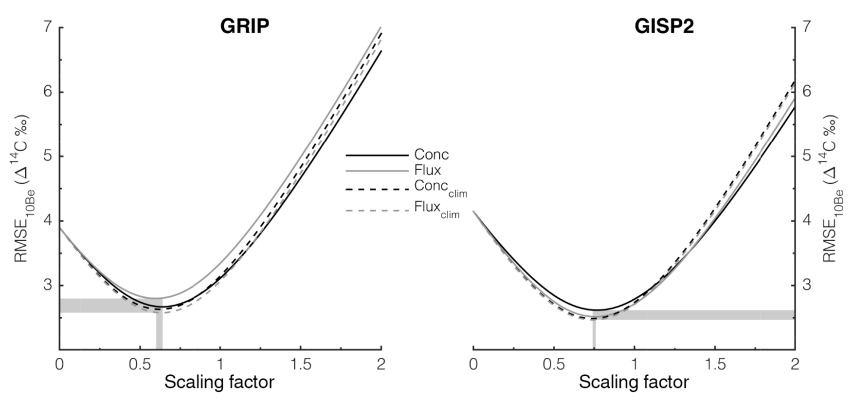

Figure 6. Rooted mean square error ( $\mathrm{RMSE}_{10} \mathrm{Be}$, see text) of synchronized centennial IntCal13 and ${ }^{10} \mathrm{Be}$-based $\Delta^{14} \mathrm{C}$ variations as a function of different ${ }^{10} \mathrm{Be}$-scaling factors $\left({ }^{14} \mathrm{C}:{ }^{10} \mathrm{Be}\right.$ ratios). Results for the different versions of the GRIP ${ }^{10} \mathrm{Be}$ record are shown on the left, while GISP2 ${ }^{10} \mathrm{Be}$-based results are shown on the right.
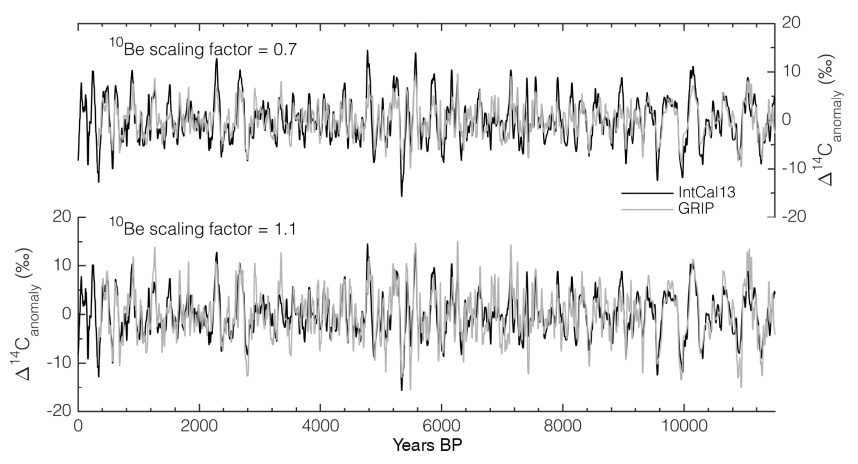

Figure 7. Comparison of synchronized tree-ring (black) and ice core (grey) based $\Delta^{14} \mathrm{C}$ anomalies for ${ }^{14} \mathrm{C}:{ }^{10} \mathrm{Be}$ ratios of 0.7 (top) and 1.1 (bottom).

can be seen that this method indicates a larger ${ }^{14} \mathrm{C}:{ }^{10} \mathrm{Be}$ ratio of about 1.1 (Fig. 8) and avoids the systematic underestimation of large amplitude $\Delta^{14} \mathrm{C}$ anomalies (Fig. 7, bottom). Depending on the production rate model used, this scaling indicates a weak (Masarik and Beer, 2009, 1999) or no (Kovaltsov et al., 2012; Kovaltsov and Usoskin, 2010) polar bias in the Greenland ${ }^{10} \mathrm{Be}$ records. In addition, it can be seen that the minimum of the RMSE ${ }_{10} \mathrm{Be}$ becomes larger than without binning, indicating an uncertainty of about $4 \%$ for the ${ }^{10} \mathrm{Be}$-based $\Delta^{14} \mathrm{C}$ records. This is due to the above-described effect, that the noise is not artificially supressed and can be seen by comparing the decadal scale peaks in the top and bottom panels of Fig. 7. The larger ${ }^{10} \mathrm{Be}$ scaling factor makes the ${ }^{10} \mathrm{Be}$ record appear noisier. However, firstly, this noise may represent remaining influences of "system effects" on ice core ${ }^{10} \mathrm{Be}$ records and, hence, represent an uncertainty that has to be taken into account. Secondly, it should be kept in mind that IntCal13 is a stack of multiple ${ }^{14} \mathrm{C}$ data sets which will inevitably result in smoothing. This smoothing may also reduce the amplitude of "real" $\Delta^{14} \mathrm{C}$ variations instead of merely reducing noise, since the differences between 


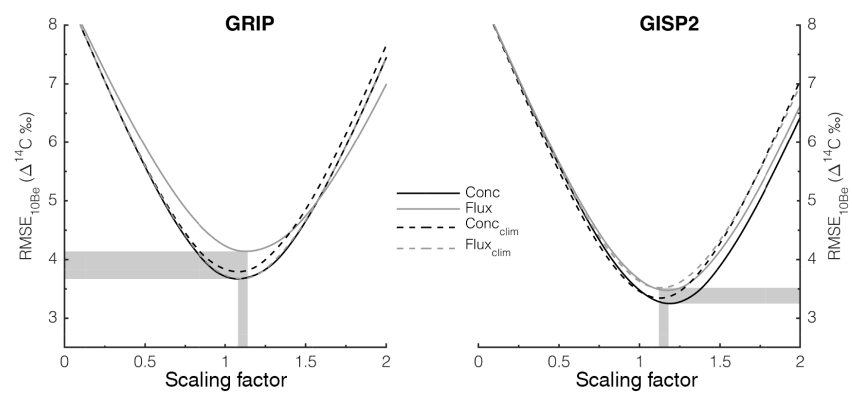

Figure 8. Rooted mean square error $\left(\mathrm{RMSE}_{10} \mathrm{Be}\right)$ of IntCal13 $\Delta^{14} \mathrm{C}$ and ${ }^{10} \mathrm{Be}$ based $\Delta^{14} \mathrm{C}$ records from GRIP (left) and GISP2 (right) for different scalings of the ${ }^{10} \mathrm{Be}$ based data after synchronization. The $\mathrm{RMSE}_{10} \mathrm{Be}$ has been calculated for binned data (bin size $=2.5 \%$, see text) taking IntCal $\Delta^{14} \mathrm{C}$ errors into account.

the underlying raw data sets of IntCal13 are potentially in part systematic (Stuiver et al., 1998; Adolphi et al., 2013).

In conclusion we use a ${ }^{14} \mathrm{C}:{ }^{10} \mathrm{Be}$ ratio of $1.1: 1$ and an uncertainty of $4 \%$ for the modelled $\Delta^{14} \mathrm{C}$ record to derive a final IntCal13-GICC05 transfer function in the next section. It should be noted that this uncertainty estimate is only valid for the centennial ( $<500$ year) variations studied here.

\subsection{IntCal13-GICC05 transfer function}

Using the estimated ${ }^{14} \mathrm{C}:{ }^{10} \mathrm{Be}$ ratio of 1.1 and a ${ }^{10} \mathrm{Be}$ based $\Delta^{14} \mathrm{C}$ error of $\pm 4 \%$ ( $\left.\pm 1 \sigma\right)$ (see previous section), we recalculated the "wiggle-match" probability distributions $\left(P_{\mathrm{s}_{\text {scaled }}}\left(t_{\mathrm{s}}\right)\right.$, Eq. 3) for the IntCal13-GICC05 timescale difference (Fig. 9, grey shading). For these calculations we used the mean of all GRIP ${ }^{10} \mathrm{Be}$-based $\Delta^{14} \mathrm{C}$ versions (concentration, flux, climate corrections) and filled the gap between 9400 and 10800 years BP using the GISP2 data. Based on these probability distributions we modelled the IntCal13GICC05 transfer function as described in Sect. 2.5. The resulting transfer function (Fig. 9 solid lines) averages out some short-term fluctuations in the timescale difference compared to the initial "wiggle-match" probability distributions. As described in Sect. 2.5 this is due to the used window length of 1000 years to determine $P_{\mathrm{s}_{\text {scaled }}}\left(t_{\mathrm{S}}\right)$ at each point in time, preventing an independent assessment of faster changes in the timescale difference. Nevertheless, the estimated uncertainties of the timescale transfer function (thin black lines in Fig. 9) encompass the uncertainties of the "wiggle-match" probability distribution at each point in time.

Figure 10 shows three examples of GRIP ${ }^{10} \mathrm{Be}$ based $\Delta^{14} \mathrm{C}$ anomalies before (grey) and after (black) synchronization to IntCal13 (red). The examples encompass (i) a period of relatively low $\Delta^{14} \mathrm{C}$ variability $( \pm 5-7 \%$ o) but good agreement between GRIP and IntCal13 (Fig. 10a), (ii) a period of large $\Delta^{14} \mathrm{C}$ variability $( \pm 10 \%$ ) but less good agreement between GRIP and IntCal13 (Fig. 10b), and (iii) a section of large $\Delta^{14} \mathrm{C}( \pm 10 \%)$ variability and excellent agreement between

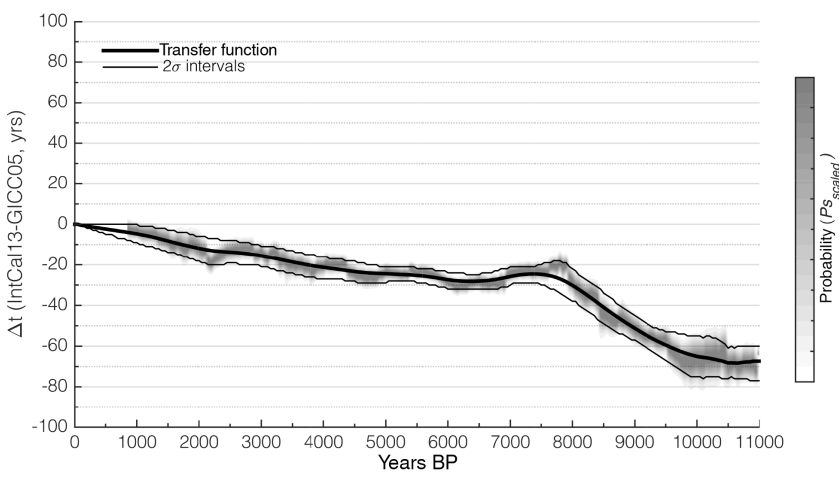

Figure 9. IntCal13-GICC05 age transfer function (thick black line) and its $2 \sigma$ confidence intervals (thin black lines) based on the probability distributions $\left(P_{\mathrm{S}_{\text {scaled }}}\left(t_{\mathrm{S}}\right)\right.$, grey shading) obtained from comparing the GRIP ${ }^{10} \mathrm{Be}$-based $\Delta^{14} \mathrm{C}$ (mean of concentration, flux and climate corrections) and IntCal13 $\Delta^{14} \mathrm{C}$ records.

GRIP and IntCal13 (Fig. 10c). It can be seen that in all cases the fit between GRIP and IntCal13 is improved when applying the proposed GICC05-IntCal13 transfer function. However, Fig. 10b also shows that short periods of disagreement (i.e., around 7250-7500 years BP) may remain, as they cannot be reliably resolved by our method which matches 1000 year long sections. It should, however, be noted that matching these short sections would (i) represent a serious violation of the GICC05 counting error which is minimal over these short periods of time ( \pm 6 years at $2 \sigma$ between 7250 7500 years BP), and (ii) not account for the possibility that ${ }^{10} \mathrm{Be}$ and ${ }^{14} \mathrm{C}$ may simply not agree due to the caveats outlined in the introduction. Furthermore, the applied shift of GICC05 in Fig. 10b) leads to an improved agreement between ${ }^{14} \mathrm{C}$ and ${ }^{10} \mathrm{Be}$ after and prior to 7250 and 7500 , respectively. Hence, we consider it unlikely that for this short period of time the timescale difference deviates significantly from the estimate for the entire window.

\section{Discussion}

Figure 11 shows the obtained estimate of the IntCal13GICC05 timescale difference in comparison to the results obtained by using the method of Muscheler et al. (2014a, re-run with a 1000 year window length) and age markers that have been independently anchored on both timescales.

Our results are fully consistent with the results obtained by Muscheler et al. (2014a). While this is expected to some extent, as our study and the work by Muscheler et al. (2014a) are based on the same data, it shows that the statistical approach used here leads to similar results as the Monte-Carlo lag-correlation analysis but is computationally much less expensive. Furthermore, as shown in Fig. 5, we obtain similar results when using the GISP $2{ }^{10} \mathrm{Be}$ instead of the GRIP ${ }^{10} \mathrm{Be}$ record lending additional support to the robustness of our results. The additional modelling of the transfer function em- 

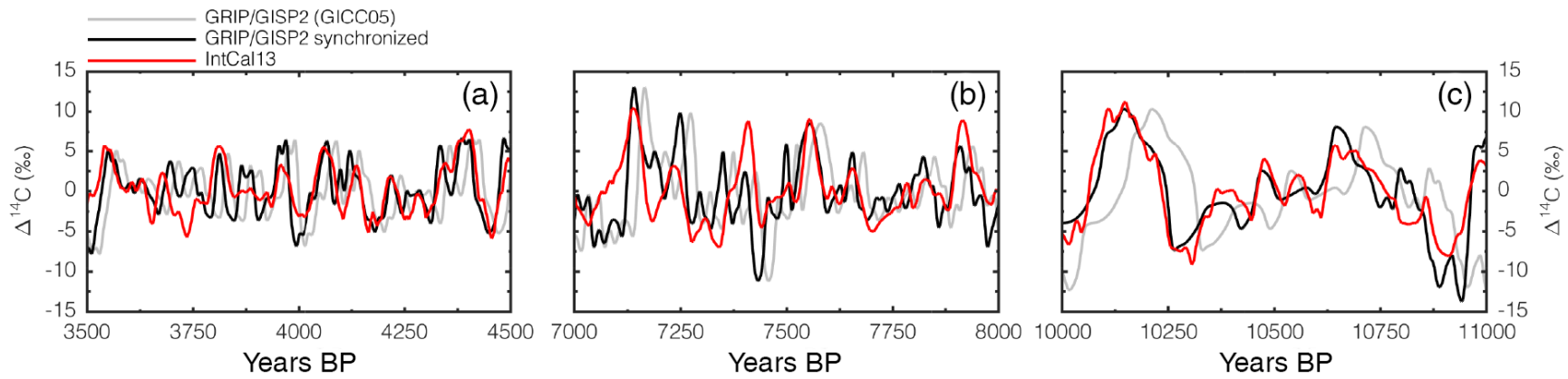

Figure 10. GRIP/GISP2 ${ }^{10} \mathrm{Be}$ based $\Delta^{14} \mathrm{C}$ before (grey) and after (black) synchronization to IntCal13 (red) for the sections (a) 3500 4500 years BP, (b) 7000-8000 years BP, (c) 10 000-11 000 years BP.

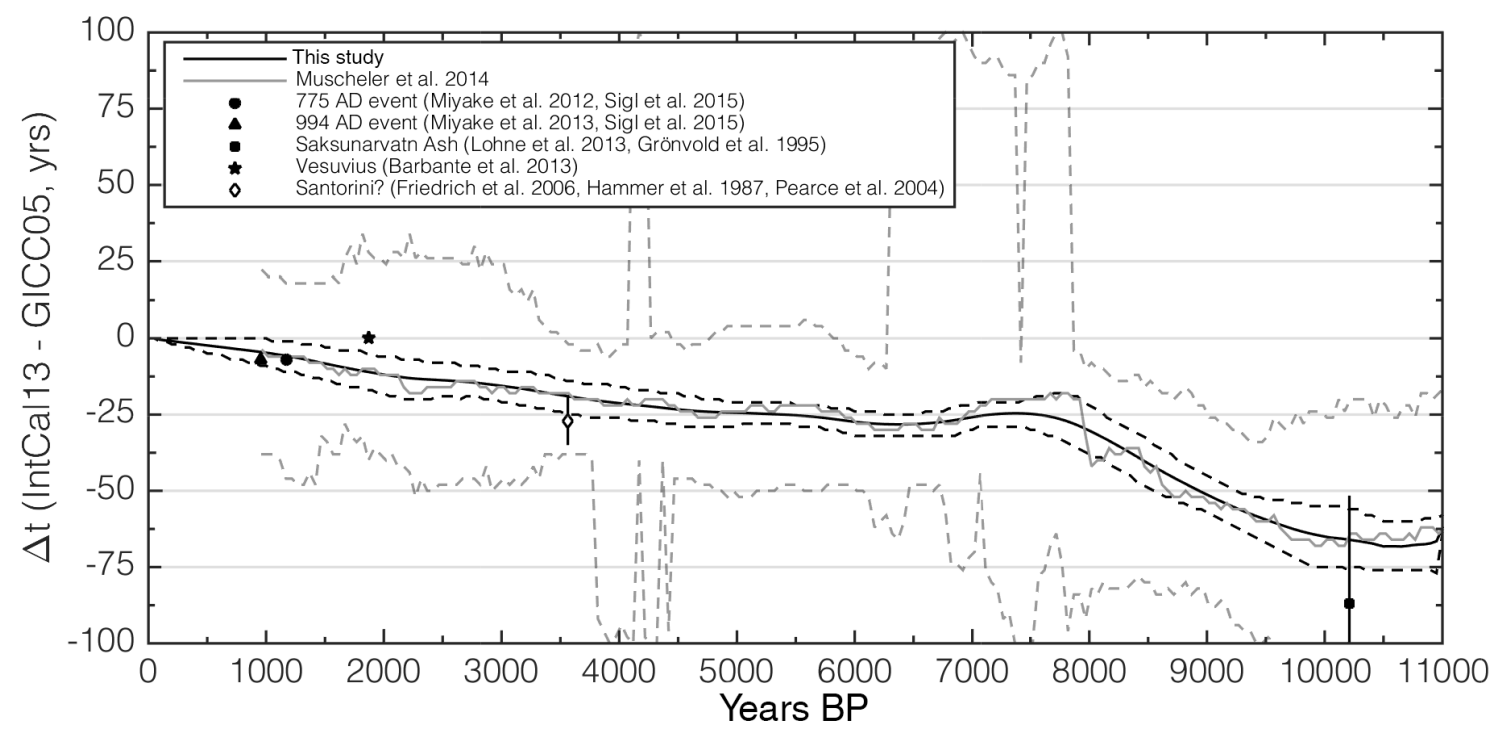

Figure 11. Comparison of the derived IntCal13-GICC05 timescale transfer function (black lines, this study) to the results by Muscheler et al. (2014a, grey lines), and independent age markers that have been linked independently to the IntCal13 and GICC05 timescales at high precision (symbols). The results of this study and Muscheler et al. (2014a) are shown with their respective $95 \%$ confidence intervals (dashed lines). The independent age markers are plotted as the difference between their estimated ages based on radiocarbon dating (Saksunarvatn Ash, Santorini), historical documents (Vesuvius) and dendrochronology (775 and 994 AD events), and their respective GICC05-ages. The plotted $1 \sigma$ error bars largely reflect uncertainties in the radiocarbon-dating and calibration of the Saksunarvatn Ash (Lohne et al., 2013) and the Santorini eruption (Friedrich et al., 2006). Note that the identification of the Santorini tephra in ice cores has been challenged based on its geochemistry (Pearce et al., 2004).

ployed here (Sects. 2.5 and 3.4) leads to a smoother development of the timescale difference which is more realistically reflecting limitations of the method imposed by the window size of the ${ }^{14} \mathrm{C}-{ }^{10} \mathrm{Be}$ comparison. The difference between the timescale transfer functions around 8200 years BP is induced by the fact that Muscheler et al. (2014a) based their calculations on ${ }^{10} \mathrm{Be}$ fluxes which are influenced by accumulation rate changes around this time as discussed in Sect. 3.2 and in Muscheler et al. (2004a).

The largest difference between the results presented here and by those of Muscheler et al. (2014a) is seen in the derived error estimates. We obtain strongly reduced uncertainties for the estimated timescale differences. This is likely due to the fact that Muscheler at al. (2014a) used a comparably ad hoc and highly conservative method to derive their uncertainties. By taking the distribution of the mean $r^{2}$ values of all iterations, Muscheler et al. (2014a) do not include the results of the Monte-Carlo analysis of the "Best Fits" in their error estimate. Thus, ${ }^{14} \mathrm{C}-{ }^{10} \mathrm{Be}$ matches that may not be the most likely solution in any of the iterations become included in the uncertainty envelope. In comparison, the statistics employed here allow a direct analytical assessment of the synchronization uncertainties. Hence, while our uncertainty estimates are significantly smaller, we consider them more robust. Theoretically, systematic errors from undetected biases in the ${ }^{10} \mathrm{Be}$ record could lead to erroneous results. However, 


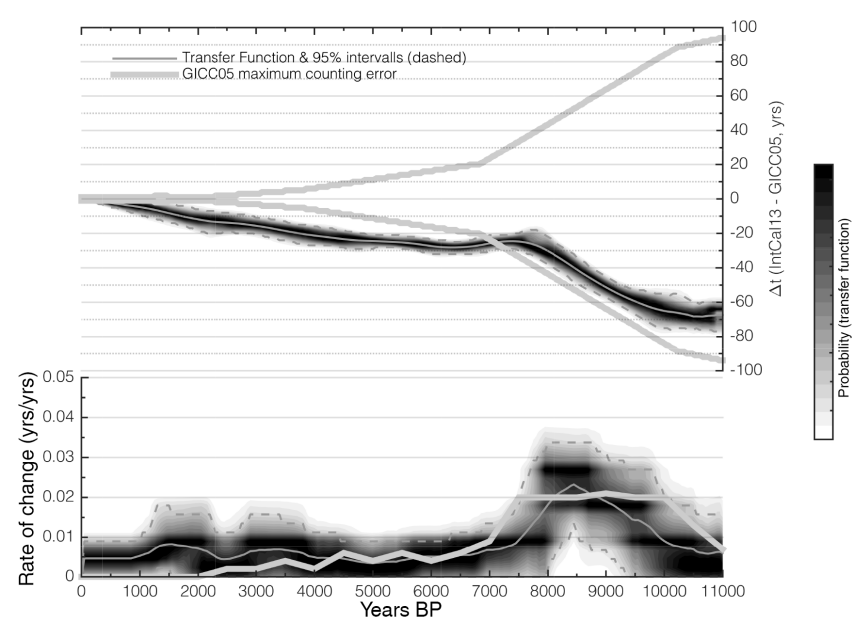

Figure 12. Top: comparison of the derived IntCal13-GICC05 transfer function (thin grey lines and shading, dashed lines denote the $95 \%$ confidence interval) to the GICC05 maximum counting error (bold grey lines). Bottom: same as above but expressed as the rate of change (year year ${ }^{-1}$ ) of the GICC05 maximum counting error and the derived timescale transfer function.

the results shown in Sect. 3.2 demonstrate the consistency of GRIP and GISP2 ${ }^{10} \mathrm{Be}$-based calculations as well as for different climate corrections and thus do not indicate such biases (see Fig. 5). In conclusion, while largely consistent, we regard the method employed here as a significant improvement to the approach by Muscheler et al. (2014a).

Comparing our results to independent estimates of IntCal13-GICC05 timescale differences further supports our analyses (Fig. 11, symbols). Two major solar proton events ("775 and 994 AD events") leaving well-defined spikes in the ${ }^{14} \mathrm{C}$ content of dendrochronologically dated trees (Miyake et al., 2012, 2013; Güttler et al., 2015) as well as in Greenland ice core ${ }^{10} \mathrm{Be}$ records (Mekhaldi et al., 2015; Sigl et al., $2015)$ indicate an IntCal13-GICC05 timescale difference of $-7 \pm 2(2 \sigma)$ years for both events (Sigl et al., 2015). Consistent with these findings, we obtain IntCal13-GICC05 differences of $-4 \pm 4$ and $-6 \pm 5$ years $(2 \sigma)$ for the 994 and 775 $\mathrm{AD}$ event, respectively. It should be noted that these annual radionuclide excursions are not present in the data used here, which is of decadal resolution, and are hence, independent estimates of the timescale difference.

Based on tephra findings in the GRIP ice core (Barbante et al., 2013), the historically dated AD 79 eruption of Vesuvius has been used as a reference point in the GICC05 chronology (Vinther et al., 2006). However, our results indicate a timescale offset of $-11 \pm 6(2 \sigma)$ years at AD 79 (1871 years BP, see Fig. 11). Assuming that the tree-ring chronologies are correct at this time, this would imply an age of AD $90 \pm 6$ for the GRIP tephra layer - incompatible with an attribution to the age of the Vesuvius eruption within $2 \sigma$. This result is in agreement with the analysis by Sigl et al. (2015) who recently counted annual layers in the NEEM and NEEM-2011-S1 ice cores and dated this marker horizon to AD 87 and 89 , respectively.

The age of the Minoan eruption of Santorini has long been debated and the presence of an unequivocally attributable signal in the ice core records has been questioned (Pearce et al., 2004; Hammer et al., 1987, 2003; Friedrich et al., 2006). The GICC05 age of $3591 \pm 5 \mathrm{BP}$ of an identified tephra horizon is incompatible with the radiocarbonbased age of $3563 \pm 14 \mathrm{calBP}$ of the Santorini eruption ( $\Delta=-28 \pm 15$ years). Our results indicate a chronology difference of $-20 \pm 5$ years around this time, reconciling the two aforementioned ages (see Fig. 11, open diamond). Hence, at least from a chronological point of view, it cannot be ruled out that the ice core tephra may be ascribable to the Santorini eruption (Muscheler, 2009).

Volcanic glass shards from the Saksunarvatn ash have been found in the GRIP ice core (Grönvold et al., 1995), as well as in multiple marine, lacustrine and terrestrial sites, of which the Lake Kråkenes record provides the highest resolution radiocarbon-based age for the deposit (Lohne et al., 2013). The dating difference of $-86 \pm 35$ years between the radiocarbon-based age $(10210 \pm 35 \mathrm{cal} \mathrm{BP}, \pm 1 \sigma$, Lohne et al. 2013) and the GICC05 age (10 296 BP, Abbott and Davies, 2012) of the Saksunarvatn ash is consistent with our estimated timescale difference of $-66 \pm 10$ years during this time interval.

In summary, our results are consistent within uncertainties with all independent age markers that link the GICC05 and IntCal13 timescales over the Holocene.

Figure 12 displays the inferred IntCal13-GICC05 timescale differences in comparison to the GICC05 maximum counting error (Rasmussen et al., 2006; Vinther et al., 2006). Assuming that the tree-ring chronologies underlying IntCal13 are accurate throughout the Holocene our results imply an underestimation of the absolute dating uncertainty of GICC05 for large parts of the Holocene. Furthermore, it can be seen that the counting error appears to be systematic, in that most uncertain years (counted as $0.5 \pm 0.5$ years, Rasmussen et al., 2006) have indeed not been true calendar years during the Holocene (i.e., a systematic over-counting of years). Nevertheless, when comparing the rate of change of the inferred IntCal13-GICC05 timescale difference to the rate of change of the maximum counting error (i.e. the relative maximum counting error) it can be seen that - even though systematic - the identification of uncertain years in the ice core records is accurate. Except for the most recent 2000 years where (potentially erroneous) fix-points like the Vesuvius eruption are used to constrain GICC05 the relative layer counting uncertainty appears to be an accurate uncertainty estimate. This can be seen in Fig. 12 (lower panel) which indicates that the rate of change of the GICC05 maximum counting error is consistent within error with the rate of change of the IntCal13-GICC05 timescale difference prior to 2000 years BP. This is important to note as it generally supports the GICC05 layer counting 
methodology and uncertainty which forms the basis of GICC05 back to 60000 years BP (Svensson et al., 2008), even though the systematic nature of the derived timescale differences challenges the use of the maximum counting error as a nearly Gaussian distributed $2 \sigma$ uncertainty during the Holocene (Andersen et al., 2006). It can, however, not be assumed that the counting error continues to be systematic beyond this period, since the parameters used for layer identification as well as the sources of uncertainty (e.g. melt layers) differ back in time under changed climatic conditions (Rasmussen et al., 2006).

Alternatively, uncertainties in the dendrochronologies underlying IntCal13 could contribute to the growing discrepancy between IntCal13 and GICC05 over the Holocene. This appears, however, unlikely since the tree-ring chronologies have been cross-dated back to 7272 cal BP to the Irish Oak Chronology (Pilcher et al., 1984) and back to 9741 cal BP using independently constructed German Oak Chronologies (Friedrich et al., 2004; Spurk et al., 2002). Furthermore, the gradual development of the timescale difference appears consistent with a counting uncertainty, while a dendrochronological mismatch could be expected to cause sudden "jumps" in the timescale difference. However, consistently missing tree rings in both German oak chronologies for the period older than 7272 cal BP could theoretically contribute to the growing timescale difference.

\section{Conclusions}

We employed a novel approach to infer timescale differences between two of the most widely used chronologies in Holocene paleoclimatology, the radiocarbon (IntCal13, Reimer et al., 2013) and Greenland ice core (GICC05, Svensson et al., 2008) timescales. Our results are largely consistent with the results of Muscheler et al. (2014a) but yield significantly smaller and more robust uncertainty estimates. The inferred timescale differences are consistent with independent tie-points obtained from volcanic tephras and solar proton events. However, in agreement with Sigl et al. (2015) our analyses indicate that the attribution of an ice core tephra to the AD 79 eruption of Vesuvius (Barbante et al., 2013) may be erroneous which leads to a propagating ice core dating bias that affects large parts of the Holocene. Nevertheless, the identification of uncertain years in the ice core during the Holocene is otherwise generally accurate as expressed in the relative counting error (Fig. 12 lower panel). This is important to note as it, in principle, supports the layer counting method and uncertainty estimates also beyond the period investigated here. Furthermore, it should be noted that these conclusions are based on the assumption that the tree-ring timescale is accurate.

Independent of the accuracy of either of the two chronologies we provided a high-precision transfer function between the radiocarbon and Greenland ice core timescales. This al- lows radiocarbon dated and ice core paleoclimate records to be compared at high chronological precision which will improve studies of leads and lags within the climate system throughout the Holocene (Bronk Ramsey et al., 2014). Furthermore, the methodology outlined here can be applied to link high-resolution ${ }^{14} \mathrm{C}$ records such as floating tree-ring chronologies to ice core timescales and thus, aid in testing and improving the glacial radiocarbon dating calibration curve.

\section{Information about the supplement}

The proposed GICC05-IntCal13 transfer function shown in Figs. 9, 11 and 12 is available as a Supplement to this paper and on NOAA.

\section{The Supplement related to this article is available online at doi:10.5194/cp-12-15-2016-supplement.}

Acknowledgements. The study was supported by the Swedish Research Council (VR) through a Linnaeus grant to Lund University (LUCCI). This work was supported by a grant from the Swedish Research Council (Dnr: 2013-8421). We thank Anders Svensson for providing GICC05 snow accumulation rates.

Edited by: L. Skinner

\section{References}

Abbott, P. M. and Davies, S. M.: Volcanism and the Greenland ice-cores: the tephra record, Earth-Sci. Rev., 115, 173-191, doi:10.1016/j.earscirev.2012.09.001, 2012.

Adolphi, F., Güttler, D., Wacker, L., Skog, G., and Muscheler, R.: Intercomparison of $14 \mathrm{C}$ dating of wood samples at Lund University and ETH-Zurich AMS facilities: extraction, graphitization, and measurement, Radiocarbon, 55, 391-400, 2013.

Adolphi, F., Muscheler, R., Svensson, A., Aldahan, A., Possnert, G., Beer, J., Sjolte, J., Björck, S., Matthes, K., and Thiéblemont, R.: Persistent link between solar activity and Greenland climate during the Last Glacial Maximum, Nat. Geosci., 7, 662-666, doi:10.1038/ngeo2225, 2014.

Alley, R. B., Finkel, R. C., Nishiizumi, K., Anandakrishnan, S., Shuman, C. A., Mershon, G., Zielinski, G. A., and Mayewski, P. A.: Changes in Continental and Sea-Salt Atmospheric Loadings in Central Greenland during the Most Recent Deglaciation - Model-Based Estimates, J. Glaciol., 41, 503-514, 1995.

Andersen, K. K., Svensson, A., Johnsen, S. J., Rasmussen, S. O., Bigler, M., Röthlisberger, R., Ruth, U., Siggaard-Andersen, M.-L., Peder Steffensen, J., and Dahl-Jensen, D.: The Greenland Ice Core Chronology 2005, 15-42ka. Part 1: constructing the time scale, Quaternary Sci. Rev., 25, 3246-3257, doi:10.1016/j.quascirev.2006.08.002, 2006. 
Barbante, C., Kehrwald, N. M., Marianelli, P., Vinther, B. M., Steffensen, J. P., Cozzi, G., Hammer, C. U., Clausen, H. B., and Siggaard-Andersen, M.-L.: Greenland ice core evidence of the 79 AD Vesuvius eruption, Clim. Past, 9, 1221-1232, doi:10.5194/cp-9-1221-2013, 2013.

Bard, E., Raisbeck, G. M., Yiou, F., and Jouzel, J.: Solar modulation of cosmogenic nuclide production over the last millennium: comparison between 14C and 10Be records, Earth Planet. Sc. Lett., 150, 453-462, doi:10.1016/s0012-821x(97)00082-4, 1997.

Blockley, S. P. E., Lane, C. S., Hardiman, M., Rasmussen, S. O., Seierstad, I. K., Steffensen, J. P., Svensson, A., Lotter, A. F., Turney, C. S. M., and Bronk Ramsey, C.: Synchronisation of palaeoenvironmental records over the last 60,000 years, and an extended INTIMATE event stratigraphy to $48,000 \mathrm{~b} 2 \mathrm{k}$, Quaternary Sci. Rev., 36, 2-10, doi:10.1016/j.quascirev.2011.09.017, 2012.

Blunier, T., Chappellaz, J., Schwander, J., Dällenbach, A., Stauffer, B., Stocker, T. F., Raynaud, D., Jouzel, J., Clausen, H. B., Hammer, C. U., and Johnsen, S. J.: Asynchrony of Antarctic and greenland climate change during the last glacial period, Nature, 394, 739-743, doi:10.1038/29447, 1998.

Bronk Ramsey, C., van der Plicht, J., and Weninger, B.: "Wiggle matching" radiocarbon dates, Radiocarbon, 43, 381-390, 2001.

Bronk Ramsey, C., Albert, P., Blockley, S., Hardiman, M., Lane, C., Macleod, A., Matthews, I. P., Muscheler, R., Palmer, A., and Staff, R. A.: Integrating timescales with time-transfer functions: a practical approach for an INTIMATE database, Quaternary Sci. Rev., 106, 67-80, doi:10.1016/j.quascirev.2014.05.028, 2014.

Buizert, C., Adrian, B., Ahn, J., Albert, M., Alley, R. B., Baggenstos, D., Bauska, T. K., Bay, R. C., Bencivengo, B. B., Bentley, C. R., Brook, E. J., Chellman, N. J., Clow, G. D., Cole-Dai, J., Conway, H., Cravens, E., Cuffey, K. M., Dunbar, N. W., Edwards, J. S., Fegyveresi, J. M., Ferris, D. G., Fitzpatrick, J. J., Fudge, T. J., Gibson, C. J., Gkinis, V., Goetz, J. J., Gregory, S., Hargreaves, G. M., Iverson, N., Johnson, J. A., Jones, T. R., Kalk, M. L., Kippenhan, M. J., Koffman, B. G., Kreutz, K., Kuhl, T. W., Lebar, D. A., Lee, J. E., Marcott, S. A., Markle, B. R., Maselli, O. J., McConnell, J. R., McGwire, K. C., Mitchell, L. E., Mortensen, N. B., Neff, P. D., Nishiizumi, K., Nunn, R. M., Orsi, A. J., Pasteris, D. R., Pedro, J. B., Pettit, E. C., Price, P. B., Priscu, J. C., Rhodes, R. H., Rosen, J. L., Schauer, A. J., Schoenemann, S. W., Sendelbach, P. J., Severinghaus, J. P., Shturmakov, A. J., Sigl, M., Slawny, K. R., Souney, J. M., Sowers, T. A., Spencer, M. K., Steig, E. J., Taylor, K. C., Twickler, M. S., Vaughn, B. H., Voigt, D. E., Waddington, E. D., Welten, K. C., Wendricks, A. W., White, J. W. C., Winstrup, M., Wong, G. J., and Woodruff, T. E.: Precise interpolar phasing of abrupt climate change during the last ice age, Nature, 520, 661-665, doi:10.1038/nature14401, 2015.

Cauquoin, A.: Use of ${ }^{10} \mathrm{Be}$ to Predict Atmospheric $14 \mathrm{C}$ Variations during the Laschamp Excursion: High Sensitivity to Cosmogenic Isotope Production Calculations, Radiocarbon, 56, 67-82, doi:10.2458/56.16478, 2014.

Delaygue, G. and Bard, E.: An Antarctic view of Beryllium-10 and solar activity for the past millennium, Clim. Dynam., 36, 22012218, doi:10.1007/s00382-010-0795-1, 2010.

Elsässer, C., Wagenbach, D., Levin, I., Stanzick, A., Christl, M., Wallner, A., Kipfstuhl, S., Seierstad, I. K., Wershofen, H., and Dibb, J.: Simulating ice core ${ }^{10} \mathrm{Be}$ on the glacial-interglacial timescale, Clim. Past, 11, 115-133, doi:10.5194/cp-11-1152015, 2015.

Field, C. V., Schmidt, G. A., Koch, D., and Salyk, C.: Modeling production and climate-related impacts on10Be concentration in ice cores, J. Geophys. Res., 111, D15107, doi:10.1029/2005jd006410, 2006.

Finkel, R. C. and Nishiizumi, K.: Beryllium 10 concentrations in the Greenland Ice Sheet Project 2 ice core from 3-40 ka, J. Geophys. Res., 102, 26699, doi:10.1029/97jc01282, 1997.

Friedrich, M., Remmele, S., Kromer, B., Hofmann, J., Spurk, M., Kaiser, K. F., Orcel, C., and Küppers, M.: The 12,460-year Hohenheim oak and pine tree-ring chronology from central Europe - a unique annual record for radiocarbon calibration and paleoenvironment reconstructions, Radiocarbon, 46, 1111-1122, 2004.

Friedrich, W. L., Kromer, B., Friedrich, M., Heinemeier, J., Pfeiffer, T., and Talamo, S.: Santorini Eruption Radiocarbon Dated to 1627-1600 B.C, Science, 312, 548, doi:10.1126/science.1125087, 2006.

Grönvold, K., Óskarsson, N., Johnsen, S. J., Clausen, H. B., Hammer, C. U., Bond, G., and Bard, E.: Ash layers from Iceland in the Greenland GRIP ice core correlated with oceanic and land sediments, Earth Planet. Sc. Lett., 135, 149-155, doi:10.1016/0012821X(95)00145-3, 1995.

Güttler, D., Adolphi, F., Beer, J., Bleicher, N., Boswijk, G., Christl, M., Hogg, A., Palmer, J., Vockenhuber, C., Wacker, L., and Wunder, J.: Rapid increase in cosmogenic ${ }^{14} \mathrm{C}$ in $\mathrm{AD} 775$ measured in New Zealand kauri trees indicates short-lived increase in ${ }^{14} \mathrm{C}$ production spanning both hemispheres, Earth Planet. Sc. Lett., 411, 290-297, doi:10.1016/j.epsl.2014.11.048, 2015.

Hammer, C. U., Clausen, H. B., Friedrich, W. L., and Tauber, H.: The Minoan eruption of Santorini in Greece dated to 1645 BC?, Nature, 328, 517-519, 1987.

Hammer, C. U., Kurat, G., Hoppe, P., Grum, W., and Clausen, H. B.: Thera eruption date 1645 BC confirmed by new ice core data?, Proceedings of the SCIEM 2000 - EuroConference Haindorf, May 2001, Haindorf, 87-93, 2003.

Heikkilä, U., Beer, J., and Feichter, J.: Meridional transport and deposition of atmospheric ${ }^{10} \mathrm{Be}$, Atmos. Chem. Phys., 9, 515-527, doi:10.5194/acp-9-515-2009, 2009.

Heikkilä, U., Beer, J., Abreu, J. A., and Steinhilber, F.: On the Atmospheric Transport and Deposition of the Cosmogenic Radionuclides $\left({ }^{10} \mathrm{Be}\right)$ : A Review, Space Sci. Rev., 176, 321-332, doi:10.1007/s11214-011-9838-0, 2011.

Heikkilä, U. and Smith, A. M.: Production rate and climate influences on the variability of ${ }^{10} \mathrm{Be}$ deposition simulated by ECHAM5-HAM: Globally, in Greenland, and in Antarctica, J. Geophys. Res.-Atmos., 118, 2506-2520, doi:10.1002/jgrd.50217, 2013.

Hogg, A. G., Turney, C. S., Palmer, J. G., Southon, J., Kromer, B., Ramsey, C. B., Boswijk, G., Fenwick, P., Noronha, A., and Staff, R.: The New Zealand kauri (Agathis australis) research project: a radiocarbon dating intercomparison of Younger Dryas wood and implications for IntCal13, Radiocarbon, 55, 2035-2048, 2013.

Johnsen, S. J., Dahl-Jensen, D., Dansgaard, W., and Gundestrup, N.: Greenland palaeotemperatures derived from GRIP bore hole temperature and ice core isotope profiles, Tellus B, 47, 624-629, doi:10.1034/j.1600-0889.47.issue5.9.x, 1995.

Köhler, P., Muscheler, R., and Fischer, H.: A model-based interpretation of low-frequency changes in the carbon cycle during 
the last 120,000 years and its implications for the reconstruction of atmospheric $\Delta^{14} \mathrm{C}$, Geochem. Geophy. Geosy., 7, Q11N06, doi:10.1029/2005GC001228, 2006.

Kovaltsov, G. A. and Usoskin, I. G.: A new 3D numerical model of cosmogenic nuclide ${ }^{10} \mathrm{Be}$ production in the atmosphere, Earth Planet. Sc. Lett., 291, 182-188, doi:10.1016/j.eps1.2010.01.011, 2010.

Kovaltsov, G. A., Mishev, A., and Usoskin, I. G.: A new model of cosmogenic production of radiocarbon ${ }^{14} \mathrm{C}$ in the atmosphere, Earth Planet. Sc. Lett., 337-338, 114-120, doi:10.1016/j.epsl.2012.05.036, 2012.

Lal, D. and Peters, B.: Cosmic ray produced radioactivity on the earth, in: Kosmische Strahlung II/Cosmic Rays II, Springer, Berlin, Heidelberg, Germany, 551-612, 1967.

Lane, C. S., Brauer, A., Blockley, S. P. E., and Dulski, P.: Volcanic ash reveals time-transgressive abrupt climate change during the Younger Dryas, Geology, 41, 1251-1254, doi:10.1130/g34867.1, 2013.

Lohne, Ø. S., Mangerud, J. A. N., and Birks, H. H.: Precise ${ }^{14} \mathrm{C}$ ages of the Vedde and Saksunarvatn ashes and the Younger Dryas boundaries from western Norway and their comparison with the Greenland Ice Core (GICC05) chronology, J. Quaternary Sci., 28, 490-500, doi:10.1002/jqs.2640, 2013.

Masarik, J. and Beer, J.: Simulation of particle fluxes and cosmogenic nuclide production in the Earth's atmosphere, J. Geophys. Res.-Atmos., 104, 12099-12111, doi:10.1029/1998jd200091, 1999.

Masarik, J. and Beer, J.: An updated simulation of particle fluxes and cosmogenic nuclide production in the Earth's atmosphere, J. Geophys. Res., 114, D11103, doi:10.1029/2008jd010557, 2009.

Mayewski, P. A., Meeker, L. D., Twickler, M. S., Whitlow, S., Yang, Q., Lyons, W. B., and Prentice, M.: Major features and forcing of high-latitude northern hemisphere atmospheric circulation using a 110,000-year-long glaciochemical series, J. Geophys. Res., 102, 26345, doi:10.1029/96jc03365, 1997.

Mekhaldi, F., Muscheler, R., Adolphi, F., Aldahan, A., Beer, J., McConnell, J. R., Possnert, G., Sigl, M., Svensson, A., Synal, H.-A., Welten, K. C., and Woodruff, T. E.: Multiradionuclide evidence for the solar origin of the cosmic-ray events of AD 774/5 and 993/4, Nature Communications, 6, 8611, doi:10.1038/ncomms9611, 2015.

Miyake, F., Nagaya, K., Masuda, K., and Nakamura, T.: A signature of cosmic-ray increase in AD 774-775 from tree rings in Japan, Nature, 486, 240-242, doi:10.1038/nature11123, 2012.

Miyake, F., Masuda, K., and Nakamura, T.: Another rapid event in the carbon-14 content of tree rings, Nature Communications, 4 , 1748, doi:10.1038/ncomms2783, 2013.

Muscheler, R.: ${ }^{14} \mathrm{C}$ and ${ }^{10} \mathrm{Be}$ around $1650 \mathrm{cal} \mathrm{BC}$, in: Time's up!: Dating the Minoan eruption of Santorini. Acts of the Minoan Eruption Chronology Workshop, Sandbjerg November 2007, edited by: Warburton, D. A., Monographs of the Danish Institute at Athens, 10, Danish Institute at Athens, Athens, 275-284, 2009.

Muscheler, R. and Heikkilä, U.: Constraints on long-term changes in solar activity from the range of variability of cosmogenic radionuclide records, Astrophysics and Space Sciences Transactions, 7, 355-364, doi:10.5194/astra-7-355-2011, 2011.

Muscheler, R., Beer, J., and Vonmoos, M.: Causes and timing of the $8200 \mathrm{yr}$ BP event inferred from the comparison of the GRIP
${ }^{10} \mathrm{Be}$ and the tree ring $\Delta^{14} \mathrm{C}$ record, Quaternary Sci. Rev., 23, 2101-2111, doi:10.1016/j.quascirev.2004.08.007, 2004a.

Muscheler, R., Beer, J., Wagner, G., Laj, C., Kissel, C., Raisbeck, G. M., Yiou, F., and Kubik, P. W.: Changes in the carbon cycle during the last deglaciation as indicated by the comparison of ${ }^{10} \mathrm{Be}$ and ${ }^{14} \mathrm{C}$ records, Earth Planet. Sc. Lett., 219, 325-340, doi:10.1016/s0012-821x(03)00722-2, 2004b.

Muscheler, R., Joos, F., Beer, J., Müller, S. A., Vonmoos, M., and Snowball, I.: Solar activity during the last 1000yr inferred from radionuclide records, Quaternary Sci. Rev., 26, 82-97, doi:10.1016/j.quascirev.2006.07.012, 2007.

Muscheler, R., Kromer, B., Björck, S., Svensson, A., Friedrich, M., Kaiser, K. F., and Southon, J.: Tree rings and ice cores reveal 14C calibration uncertainties during the Younger Dryas, Nat. Geosci., 1, 263-267, doi:10.1038/ngeo128, 2008.

Muscheler, R., Adolphi, F., and Knudsen, M. F.: Assessing the differences between the IntCal and Greenland ice-core time scales for the last 14,000 years via the common cosmogenic radionuclide variations, Quaternary Sci. Rev., 106, 81-87, doi:10.1016/j.quascirev.2014.08.017, 2014a.

Muscheler, R., Adolphi, F., and Svensson, A.: Challenges in ${ }^{14} \mathrm{C}$ dating towards the limit of the method inferred from anchoring a floating tree ring radiocarbon chronology to ice core records around the Laschamp geomagnetic field minimum, Earth Planet. Sc. Lett., 394, 209-215, doi:10.1016/j.epsl.2014.03.024, 2014 b.

Oeschger, H., Siegenthaler, U., Schotterer, U., and Gugelmann, A.: A box diffusion model to study the carbon dioxide exchange in nature, Tellus, 27, 168-192, doi:10.1111/j.21533490.1975.tb01671.x, 1975.

Pearce, N. J. G., Westgate, J. A., Preece, S. J., Eastwood, W. J., and Perkins, W. T.: Identification of Aniakchak (Alaska) tephra in Greenland ice core challenges the 1645 BC date for Minoan eruption of Santorini, Geochem. Geophy. Geosy., 5, Q03005, doi:10.1029/2003GC000672, 2004.

Pedro, J. B., Heikkilä, U. E., Klekociuk, A., Smith, A. M., van Ommen, T. D., and Curran, M. A. J.: Beryllium-10 transport to Antarctica: Results from seasonally resolved observations and modeling, J. Geophys. Res.-Atmos., 116, D23120, doi:10.1029/2011jd016530, 2011a.

Pedro, J. B., Smith, A. M., Simon, K. J., van Ommen, T. D., and Curran, M. A. J.: High-resolution records of the beryllium-10 solar activity proxy in ice from Law Dome, East Antarctica: measurement, reproducibility and principal trends, Clim. Past, 7, 707-721, doi:10.5194/cp-7-707-2011, 2011 b.

Pedro, J. B., McConnell, J. R., van Ommen, T. D., Fink, D., Curran, M. A. J., Smith, A. M., Simon, K. J., Moy, A. D., and Das, S. B.: Solar and climate influences on ice core ${ }^{10} \mathrm{Be}$ records from Antarctica and Greenland during the neutron monitor era, Earth Planet. Sc. Lett., 355-356, 174-186, doi:10.1016/j.eps1.2012.08.038, 2012.

Pilcher, J. R., Baillie, M. G. L., Schmidt, B., and Becker, B.: A 7,272-year tree-ring chronology for western Europe, Nature, 312, 150-152, 1984.

Raisbeck, G. M., Yiou, F., Fruneau, M., Loiseaux, J. M., Lieuvin, M., and Ravel, J. C.: Cosmogenic ${ }^{10} \mathrm{Be} /{ }^{7} \mathrm{Be}$ as a probe of atmospheric transport processes, Geophys. Res. Lett., 8, 1015-1018, doi:10.1029/GL008i009p01015, 1981.

Rasmussen, S. O., Andersen, K. K., Svensson, A. M., Steffensen, J. P., Vinther, B. M., Clausen, H. B., Siggaard-Andersen, M. 
L., Johnsen, S. J., Larsen, L. B., Dahl-Jensen, D., Bigler, M., Röthlisberger, R., Fischer, H., Goto-Azuma, K., Hansson, M. E., and Ruth, U.: A new Greenland ice core chronology for the last glacial termination, J. Geophys. Res., 111, D06102, doi:10.1029/2005jd006079, 2006.

Reimer, P. J., Bard, E., Bayliss, A., Beck, J. W., Blackwell, P. G., Bronk Ramsey, C., Buck, C. E., Cheng, H., Edwards, R. L., Friedrich, M., Grootes, P. M., Guilderson, T. P., Haflidason, H., Hajdas, I., Hatté, C., Heaton, T. J., Hoffmann, D. L., Hogg, A. G., Hughen, K. A., Kaiser, K. F., Kromer, B., Manning, S. W., Niu, M., Reimer, R. W., Richards, D. A., Scott, E. M., Southon, J. R., Staff, R. A., Turney, C. S. M., and van der Plicht, J.: IntCal13 and Marine13 Radiocarbon Age Calibration Curves 0-50,000 Years cal BP, Radiocarbon, 55, 1869-1887, 2013.

Roth, R. and Joos, F.: A reconstruction of radiocarbon production and total solar irradiance from the Holocene ${ }^{14} \mathrm{C}$ and $\mathrm{CO}_{2}$ records: implications of data and model uncertainties, Clim. Past, 9, 1879-1909, doi:10.5194/cp-9-1879-2013, 2013.

Seierstad, I. K., Abbott, P. M., Bigler, M., Blunier, T., Bourne, A. J., Brook, E., Buchardt, S. L., Buizert, C., Clausen, H. B., Cook, E., Dahl-Jensen, D., Davies, S. M., Guillevic, M., Johnsen, S. J., Pedersen, D. S., Popp, T. J., Rasmussen, S. O., Severinghaus, J. P., Svensson, A., and Vinther, B. M.: Consistently dated records from the Greenland GRIP, GISP2 and NGRIP ice cores for the past $104 \mathrm{ka}$ reveal regional millennial-scale $\delta^{18} \mathrm{O}$ gradients with possible Heinrich event imprint, Quaternary Sci. Rev., 106, 2946, doi:10.1016/j.quascirev.2014.10.032, 2014.

Siegenthaler, U., Heimann, M., and Oeschger, H.: ${ }^{14} \mathrm{C}$ variations caused by changes in the global carbon cycle, Radiocarbon, 22, 177-191, 1980.

Sigl, M., Winstrup, M., McConnell, J. R., Welten, K. C., Plunkett, G., Ludlow, F., Buntgen, U., Caffee, M., Chellman, N., Dahl-Jensen, D., Fischer, H., Kipfstuhl, S., Kostick, C., Maselli, O. J., Mekhaldi, F., Mulvaney, R., Muscheler, R., Pasteris, D. R., Pilcher, J. R., Salzer, M., Schupbach, S., Steffensen, J. P., Vinther, B. M., and Woodruff, T. E.: Timing and climate forcing of volcanic eruptions for the past 2,500 years, Nature, 523, 543-549, doi:10.1038/nature14565, 2015.
Southon, J.: A First Step to Reconciling the GRIP and GISP2 IceCore Chronologies, 0-14,500 yr B.P, Quaternary Res., 57, 32 37, doi:10.1006/qres.2001.2295, 2002.

Spurk, M., Leuschner, H. H., Baillie, M. G. L., Briffa, K. R., and Friedrich, M.: Depositional frequency of German subfossil oaks: climatically and non-climatically induced fluctuations in the Holocene, The Holocene, 12, 707-715, doi:10.1191/0959683602hl583rp, 2002.

Stuiver, M., Braziunas, T. F., Grootes, P. M., and Zielinski, G. A.: Is There Evidence for Solar Forcing of Climate in the GISP2 Oxygen Isotope Record?, Quaternary Res., 48, 259-266, doi:10.1006/qres.1997.1931, 1997.

Stuiver, M., Reimer, P. J., Bard, E., Beck, J. W., Burr, G. S., Hughen, K., Kromer, B., McCormac, F. G., Van der Plicht, J., and Spurk, M.: INTCAL98 radiocarbon age calibration, 24000-0 cal BP, Radiocarbon, 40, 1041-1083, 1998.

Svensson, A., Andersen, K. K., Bigler, M., Clausen, H. B., DahlJensen, D., Davies, S. M., Johnsen, S. J., Muscheler, R., Parrenin, F., Rasmussen, S. O., Röthlisberger, R., Seierstad, I., Steffensen, J. P., and Vinther, B. M.: A 60000 year Greenland stratigraphic ice core chronology, Clim. Past, 4, 47-57, doi:10.5194/cp-4-472008, 2008.

Vinther, B. M., Clausen, H. B., Johnsen, S. J., Rasmussen, S. O., Andersen, K. K., Buchardt, S. L., Dahl-Jensen, D., Seierstad, I. K., Siggaard-Andersen, M. L., Steffensen, J. P., Svensson, A., Olsen, J., and Heinemeier, J.: A synchronized dating of three Greenland ice cores throughout the Holocene, J. Geophys. Res., 111, D13102, doi:10.1029/2005jd006921, 2006.

Vonmoos, M., Beer, J., and Muscheler, R.: Large variations in Holocene solar activity: Constraints from ${ }^{10} \mathrm{Be}$ in the Greenland Ice Core Project ice core, J. Geophys. Res., 111, A10105, doi:10.1029/2005ja011500, 2006.

Yiou, F., Raisbeck, G. M., Baumgartner, S., Beer, J., Hammer, C., Johnsen, S., Jouzel, J., Kubik, P. W., Lestringuez, J., Stiévenard, M., Suter, M., and Yiou, P.: Beryllium 10 in the Greenland Ice Core Project ice core at Summit, Greenland, J. Geophys. Res., 102, 26783, doi:10.1029/97jc01265, 1997. 